Article

\title{
Side Lighting Enhances Morphophysiology and Runner Formation by Upregulating Photosynthesis in Strawberry Grown in Controlled Environment
}

\author{
Jingli Yang ${ }^{1(\mathbb{D}}$, Jinnan Song ${ }^{1(\mathbb{D})}$ and Byoung Ryong Jeong ${ }^{1,2,3, *(\mathbb{D})}$ \\ 1 Department of Horticulture, Division of Applied Life Science (BK21 Four), Graduate School of Gyeongsang \\ National University, Jinju 52828, Korea; yangmiaomiaode@gmail.com (J.Y.); jinnansong93@gmail.com (J.S.) \\ 2 Institute of Agriculture and Life Science, Gyeongsang National University, Jinju 52828, Korea \\ 3 Research Institute of Life Science, Gyeongsang National University, Jinju 52828, Korea \\ * Correspondence: brjeong@gnu.ac.kr; Tel.: +82-55-772-1913
}

check for updates

Citation: Yang, J.; Song, J.; Jeong, B.R. Side Lighting Enhances Morphophysiology and Runner Formation by Upregulating Photosynthesis in Strawberry Grown in Controlled Environment. Agronomy 2022, 12, 24. https:// doi.org/10.3390/agronomy12010024

Academic Editor: Mick Fuller

Received: 24 November 2021

Accepted: 21 December 2021

Published: 23 December 2021

Publisher's Note: MDPI stays neutral with regard to jurisdictional claims in published maps and institutional affiliations.

Copyright: (C) 2021 by the authors. Licensee MDPI, Basel, Switzerland. This article is an open access article distributed under the terms and conditions of the Creative Commons Attribution (CC BY) license (https:// creativecommons.org/licenses/by/ $4.0 /)$

\begin{abstract}
The significant effects of lighting on plants have been extensively investigated, but research has rarely studied the impact of different lighting directions for the strawberry plant. To understand the optimal lighting direction for better growth and development, this study investigated how strawberries respond to variations in the lighting direction to help fine-tune the growth environment for their development. We examined how the lighting direction affects plant morphophysiology by investigating plant growth parameters, leaf anatomy, epidermal cell elongation, stomatal properties, physiological characteristics, and expressions of runner induction-related genes (FaSOC1 and FaTFL1) and gibberellin (GA) biosyntheses-related genes (FaGA20ox2 and FaGA20ox4). In closed-type plant factory units, the rooted cuttings of strawberry (Fragaria $\times$ ananassa Duch.) 'Suhlyang' were subjected to a 10 -h photoperiod with a $350 \mu \mathrm{mol} \cdot \mathrm{m}^{-2} \cdot \mathrm{s}^{-1}$ photosynthetic photon flux density (PPFD) provided by light-emitting diodes (LEDs) from three directions relative to the plants: top, side, and bottom. Our results demonstrated that the side lighting profoundly promoted not only morphophysiology, but also runner formation, by upregulating photosynthesis in strawberries. Side lighting can bring commercial benefits, which include reduced economic costs, easier controllability, and harmlessness to plants. This will help provide new insights for the propagation of the most commonly cultivated strawberries in South Korea.
\end{abstract}

Keywords: lighting direction; photomorphogenesis; photosynthesis; phototropism; plant factorytype chamber; runner induction; strawberry propagation

\section{Introduction}

Cultivated strawberry (Fragaria $\times$ ananassa Duch.) is one of the most popular crops worldwide due to its flavor, graceful appearance, and health benefits. Strawberry cultivation and production have steadily expanded during the last two decades [1]. Strawberry can easily be grown via crown division or with daughter plants on runners. Strawberry plants are commercially propagated, often utilizing daughter plants grown on runners, as asexual generation of daughter plants is faster than seed propagation, and daughter plants preserve the traits of the mother plants [2]. Hence, the ability to generate runners is extremely important in agriculture. Strawberry is a rosette-forming plant, with a short stem, which is known as the primary crown [3]. At the axils of leaves on the primary crown, there is an axillary meristem (AXM) which can either develop into runners, branch crowns, or remain dormant [4]. It has long been known that the process of generating runners and flowers from various meristem crowns in wild and cultivated strawberries are antagonistic. In addition, these processes are dependent on the cultivar and various environmental factors [2]. It is well known that long days and high temperatures will promote runner formation [5], as well as the plant growth regulators (PGRs) which are essential for AXM initiation and axillary bud growth [6]. The most well-known PGRs for runner induction are 
GAs. Numerous studies have shown that GAs can significantly promote runner formation in both wild and cultivated strawberries [7-9]. Therefore, the development of the AXM is extremely important for runner production.

Commercially, growing strawberries indoors has become more popular, because it avoids many adverse environmental effects and improves the quality and quantity of agricultural products. Growing plants indoors in plant growth chambers, plant factories, and greenhouses allows the use of highly controllable artificial lighting as a supplement. The applications of Plant Artificial Lights (PALs) will replace sunlight to provide light for agricultural production. Indoor plant cultivation with artificial lighting is an innovative technology for modern agriculture that fundamentally changes the concept of farming [10]. Moreover, how to select the correct lighting for indoor plant cultivation has become a subject of great interest.

Lighting is a crucial factor for plant growth. Since plants are sessile and photoautotrophic, they cannot move away from sources of stress or seek out a location with optimal environmental conditions [11]. Instead, in order to live and reproduce in their environment, they must adapt their development mechanisms to their environment. Many species have evolved complex photosensory systems that allow them to properly respond to their surroundings [12]. Light is required for photosynthesis and many other physiological processes related to plant development, and plants are extremely sensitive to this vital external signal [13]. Plant survival is largely dependent on light adaptation [14]. Photomorphogenesis, a specific talent developed by more advanced plants, allows them to change their forms in response to the changing light conditions [15]. Lighting direction is a new concept that is different from the light quality and intensity that affects plant morphophysiology. Variations in the lighting direction affect plant morphophysiology. The leaf orientation directly determines the light interception. Phototropism-induced variations in the leaf angle and leaf movement (epinastic or hyponastic) have been proposed as a way for plants to develop a greater photosynthetic capacity and efficiency [16].

As mentioned in our previous study, the lighting direction affected the plant morphology, as evidenced by the growth parameters, epidermal cell elongation, stomatal properties, and physiological changes with the changing light directions [17,18]. Due to changes in the leaf angle followed by variations in the lighting direction, the epidermal cells in the midribs are stimulated, which further affects the stomatal characteristics. The stomatal density and size are thought to be indications of plants' acclimatization and adaptability to different conditions [19,20]. Moreover, an increased stomatal density decreases the risk of stomatal injury from various stresses, such that having a very dense and opened smaller stomata is the optimal strategy for attaining the largest stomatal conductance at low $\mathrm{CO}_{2}$ concentrations, which helps plants achieve a high photosynthetic efficiency [21]. Furthermore, variations in the lighting direction also affected the photosynthetic and chlorophyll fluorescence parameters of plants. Chlorophyll fluorescence measurements have long been recognized as a useful and informative indication for assessing various photosynthetic responses [22]. Chlorophyll fluorescence is primarily and successfully utilized to determine the possible quantum yield of photosystem II and photoinhibition under prevailing light and shade environments [23]. Shade has a substantial impact on the performance and structure of the photosynthetic apparatus [24]. It reduces the thicknesses of leaves, palisades, and spongy tissues, and inhibits energy transfer from PSII to PSI, resulting in a reduced chlorophyll fluorescence [24,25]. In addition, enzymatic activities are also influenced by different lighting directions. Plants have developed sophisticated acclimatization strategies to overcome unfavorable conditions, such as the ROS (reactive oxygen species) scavenged enzymatic antioxidant system [26]. Under this condition, the balance between the production of ROS and the quenching activity of antioxidants becomes disrupted, often resulting in oxidative damages [27]. Usually, a greater ability to eliminate ROS indicates higher antioxidant enzyme activities. Moreover, chlorophyll a is more sensitive to ROS than chlorophyll $b$ is under stressed conditions. ROS directly causes the degradation of chlorophyll a, and the total chlorophyll contents [28,29], which affects photosynthesis. Moreover, the 
metabolic capacity of photosynthesis in plants has been evaluated through the quantity and activity of key enzymes involved in the $\mathrm{CO}_{2}$ fixation and the regeneration of RuBisCO-1, 5-bisphosphate (RuBP) under various circumstances [30-32], as well as the content and activity of light-capturing components, electron transport fragments, and energy transferring enzymes [33-35]. RuBisCO (RuBP carboxylase or oxygenase) catalyzes the $\mathrm{CO}_{2}$ fixation in photosynthesis, which is directly engaged in the first phase of the Calvin Benson cycle and accounts for $12-35 \%$ of the leaf proteins, most notably in $C_{3}$ crop plants [36]. The primary biochemical constraint implicated in the shade-associated down-regulation of the net photosynthetic rate has been identified in previous reports as a decrease in the RuBisCO quantity or activity [30]. Most notably, side lighting promoted more branches and flowers in chrysanthemum plants [18]. Thus, these findings indicate the importance of investigating the responses of plant performance under changing light directions to understand how the growth and development of plants are affected by different lighting directions.

In addition to external influences, researchers have lately started to focus on the genetic factors affecting the runner formation in strawberries. Diploid woodland strawberry (Fragaria vesca) has been developed as a model for the commercial strawberry (octoploid) because of its small genome size [37]. Tenreira and his colleagues [38] found that the runnerless trait in woodland strawberry was caused by a deletion in the active site of a GA-biosynthesis gene named FveGA20ox. This mutation was also found in all-natural runnerless woodland strawberry plants, and exogenous applications of bioactive GAs restored the runner-producing phenotype in the runnerless plants. Moreover, Mouhu et al. [39] suggested that FveSOC1 plays a central role in the photoperiodic control of runner production and flowering in woodland strawberries, and this process may also be regulated through the activation of GA-biosynthesis genes. These results strongly suggest that GA biosynthesis in the axillary meristem is essential for inducing runner differentiation in diploid strawberry plants [40].

In this study, we investigated how strawberries respond to the different lighting directions to help fine-tune the growth environment for their development. Furthermore, our study not only refers to the profound effects of the lighting direction on the morphophysiology of strawberries but also demonstrated how the runner formation was visibly induced by side lighting. It avoids the side effects of inappropriate working concentrations of PGRs, and only adjusts lighting directions, which is easier to control, reduces economic costs, and poses no harms to the plant itself. However, the exact mechanism still needs to be further explored. These findings will provide new insights for the propagation of the most commonly cultivated strawberries in South Korea.

\section{Materials and Methods}

\subsection{Plant Growth and Treatment Designs}

The runner plants of strawberry 'Sulhyang' were obtained from a strawberry farm (Sugok-myeon, Jinju, Gyeongsangnam-do, Korea) in mid-July of 2021. They were stuck in a commercial medium (BVB Medium, Bas Van Buuren Substrates, EN-12580, De Lier, The Netherlands) in 21-cell zigzag trays (21-Zigpot/21 cell tray, Daeseung, Jeonju, Korea). All cuttings were kept on a fogged propagation bench with an $80 \%$ relative humidity for 15 days, and were subsequently acclimated for 7 days in a glasshouse with an average light intensity of $350 \mu \mathrm{mol} \cdot \mathrm{m}^{-2} \cdot \mathrm{s}^{-1}$ PPFD of sunlight, and a natural photoperiod. The strawberry plants with $3 \pm 1$ leaves per plant were transplanted into $10 \mathrm{~cm}$ plastic pots for the subsequent experiments.

After acclimation, the transplanted plants were randomly divided into nine groups, where each group contained six biological replications $(n=6)$ with consistent growth to minimize the external influences and transferred into three separate closed-type plant growth chambers (C1200H3, FC Poibe Co. Ltd., Seoul, Korea), which acted as three experimental repetitions, with a $25{ }^{\circ} \mathrm{C}$ temperature and $80 \%$ relative humidity. Each chamber was divided equally into compartments according to the three lighting directions 
(top, side, and bottom) using plates. The compartments with different lighting directions had a random distribution of positions in each chamber to avoid the occurrence of effects related to the position. In addition, all light-reflecting parts inside the chambers and the plates of each layer were wrapped with an opaque black curtain to prevent the different lighting directions from interacting with each other. Each plate contained one group of plants, with $15 \mathrm{~cm}$ between each plant. The LEDs used were custom-made (SungKwang LED Co., Ltd., Incheon, Korea) and produced a wide spectrum, ranging from 400 to $720 \mathrm{~nm}$ with a distinct peak at $435 \mathrm{~nm}$ (blue) at a set light intensity of $350 \mu \mathrm{mol} \cdot \mathrm{m}^{-2} \cdot \mathrm{s}^{-1} \mathrm{PPFD}$ from 08:00 to 18:00 (SD condition) via an adjustment of the dimmer. Moreover, two modulartype LED lamps were placed $15 \mathrm{~cm}$ away from the top, side, or bottom of the plants. Furthermore, the light intensity was measured using a quantum radiation probe (FLA 623 PS, ALMEMO, Holzkirchen, Germany) at the top-leaf level of the plant [17]. The plants were watered every day at 09:00 a.m. from 7 August to 20 September, 2021 with a nutrient solution with a composition of (in mg. $\mathrm{L}^{-1}$ ) $708.0 \mathrm{Ca}\left(\mathrm{NO}_{3}\right)_{2} \cdot 4 \mathrm{H}_{2} \mathrm{O}, 246.0 \mathrm{MgSO}_{4} \cdot 7 \mathrm{H}_{2} \mathrm{O}$, $505.0 \mathrm{KNO}_{3}, 230.0 \mathrm{NH}_{4} \mathrm{H}_{2} \mathrm{PO}_{4}, 1.24 \mathrm{H}_{3} \mathrm{BO}_{3}, 0.12 \mathrm{CuSO}_{4} \cdot 5 \mathrm{H}_{2} \mathrm{O}, 4.00$ Fe-ethylene diamine tetraacetic acid, $2.20 \mathrm{MnSO}_{4} \cdot 4 \mathrm{H}_{2} \mathrm{O}, 0.08 \mathrm{H}_{2} \mathrm{MoO}_{4}$, and $1.15 \mathrm{ZnSO}_{4} \cdot 7 \mathrm{H}_{2} \mathrm{O}$ [17].

\subsection{Measurements of the Growth Parameters}

The growth indexes were collected after 45 days of cultivation. The plants were harvested and immediately put into liquid nitrogen, then stored in a $-80^{\circ} \mathrm{C}$ freezer for future physiological investigations. Whole plants were obtained, and the roots were properly cleaned with tap water and severed from the shoot to measure the growth parameters. The plant height, top view diameter of plants, number of leaves and runners per plant, length and width of the largest fully-expanded leaves, the abaxial petiole angle of the outermost leaves, root length, and the fresh weights of shoots and roots were measured directly. In addition, the dry weights of the shoots and roots were measured after drying for one week in a $65^{\circ} \mathrm{C}$ drying oven.

\subsection{Leaf Anatomical Features}

For each treatment, six leaf segments $\left(1 \mathrm{~cm}^{2}\right)$ without midribs were collected from fully expanded leaves in the same development stage for each treated plant. The segments were fixed in a formaldehyde solution containing $5 \%(v / v)$ formalin, $5 \%(v / v)$ acetic acid, and $90 \%(v / v)$ ethanol at $4{ }^{\circ} \mathrm{C}$ for one week. The leaf samples were dehydrated in a graded series of ethanol solutions $(95,75,50,25$, and $10 \%(v / v)$ ethanol for each treatment for $45 \mathrm{~min}$ with three repeats, respectively) and cut using the freehand slice method to an appropriate thickness. The sections were placed on glass slides and then directly observed with an optical microscope (ECLIPSE Ci-L, Nikon Corporation, Tokyo, Japan) without staining. The thicknesses of the total leaf, spongy tissues, and palisade mesophylls were measured with ImageJ.

\subsection{Epidermal Cell and Stomatal Characteristics}

The upper and lower epidermis without leaf midribs were carefully removed from the fully expanded leaves of three randomly selected plants in a similar position for each lighting direction to observe the epidermal cells. An observation of the stomata was performed using transparent gummed tape to tear the epidermis from the abaxial surfaces of leaves [41]. The excised samples were observed with an optical microscope (ECLIPSE Ci-L, Nikon Corporation, Tokyo, Japan) and analyzed with ImageJ. The number of stomata was divided by the area in which the number of stomata was recorded to obtain the stomatal density. The length and width of guard cell pairs and stomatal pores were measured according to the directions provided by Sack and Buckley [19].

\subsection{Photosynthesis and Photosynthetic Pigment Contents}

A leaf porometer (SC-1, Decagon Device Inc., Pullman, WA, USA) was used to measure the photosynthetic parameters of fully expanded leaves at the same stage and position. 
All parameters, including the net photosynthetic rate $\left(P_{n}\right)$, transpiration rate $\left(T_{\mathrm{r}}\right)$, stomatal conductance $\left(G_{\mathrm{s}}\right)$, and intercellular $\mathrm{CO}_{2}$ concentration $\left(C_{\mathrm{i}}\right)$ were measured inside the plant growth chambers to maintain the same steady condition from 9:30 to 11:30 in the morning. $0.2 \mathrm{~g}$ samples of fresh leaves were collected from each treated plant for photosynthetic pigment content measurements $(n=6)$. All of the samples were dipped in $10 \mathrm{~mL} \mathrm{~N}, \mathrm{~N}$ dimethyl formamide solution in the dark for $48 \mathrm{~h}$ at $4{ }^{\circ} \mathrm{C}$, and then both chlorophyll a (Chl

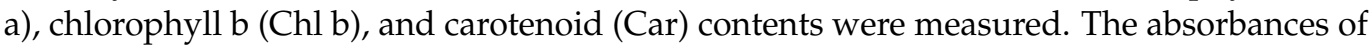
the upper layer solution at 645 and $663 \mathrm{~nm}$ were recorded with a UV spectrophotometer (Libra S22, Biochrom Ltd., Cambridge, UK). The photosynthetic pigment content was calculated according to the method described by Sim et al. [42]. The pigment content was expressed as the pigment content/fresh leaf weight $(\mathrm{mg} / \mathrm{g})$.

\subsection{Chlorophyll Fluorescence Measurements}

The chlorophyll fluorescence measurement was performed with the miniaturized pulse-amplitude-modulated photosynthesis yield. Each plant was moved to a dark chamber for $45 \mathrm{~min}$ for adaptation before being measured. A photosystem (Fluor Pen FP 100, Photon Systems Instruments, PSI, Drásov, Czech Republic) was used to estimate the maximal PSII quantum yield $(F \mathrm{v} / F \mathrm{~m})$, photochemical efficiency of PSII $\left(F \mathrm{v}^{\prime} / F \mathrm{~m}^{\prime}\right)$, non-photochemical quenching (NPQ), and the coefficient of photochemical quenching $(q P)$. All the parameters were calculated using the methods reported by Maxwell et al. [43].

\subsection{Contents of Carbohydrates and Soluble Proteins}

The leaf samples were harvested at the same stage at the end of the day or night for the carbohydrate measurements. The contents of starch and soluble sugars were determined by the Anthrone colorimetric method described by Vasseur and Ren et al. [44,45]. The total proteins in the strawberry leaves were extracted based on the methods of Bianco et al. [46] with minor modifications. The fresh leaves were collected, immediately immersed in liquid nitrogen, and were ground into a fine powder over an ice bath. A total of $0.5 \mathrm{~g}$ of the powder was transferred into a $15 \mathrm{~mL}$ centrifuge tube and was suspended with a $5 \mathrm{~mL}$ extraction buffer (0.7 M sucrose, $0.1 \mathrm{M} \mathrm{KCl}, 0.5 \mathrm{M}$ Tris- $\mathrm{HCl}$ (pH 7.5), $50 \mathrm{mM}$ EDTA, $\%$ $(w / v)$ PVP, $2 \%(w / v) \beta$-mercaptoethanol, $1 \mathrm{mM}$ PSMF, and $10 \mathrm{mM}$ DTT). The tube was kept in ice for $30 \mathrm{~min}$ before an equal volume of chilled phenol saturated with a Tris- $\mathrm{HCl}$ buffer ( $\mathrm{pH} 7.5$ ) was added, and then was vortexed for $25 \mathrm{~min}$. After a 20-min centrifugation $\left(13,000 \mathrm{rpm}, 4^{\circ} \mathrm{C}\right)$, the upper phenolic phase was collected and mixed with 5 volumes of $100 \mathrm{mM}$ ammonium acetate in methanol, then was kept at $-20^{\circ} \mathrm{C}$ overnight. The precipitated proteins were centrifuged $\left(13,000 \mathrm{rpm}, 4^{\circ} \mathrm{C}, 35 \mathrm{~min}\right)$, and then rinsed once with pre-cooled methanol and twice with chilled $80 \%(v / v)$ acetone. The proteins were then air-dried at room temperature and dissolved in a $400 \mu \mathrm{L}$ rehydration buffer $(7 \mathrm{M}$ urea, $2 \mathrm{M}$ thiourea, $4 \%(w / v)$ CHAPS, $2 \%(w / v)$ IPG, and $0.001 \%(w / v)$ bromophenol blue). Finally, the total soluble protein content was determined with the Bradford reagent (Sigma-Aldrich, St. Louis, MO, USA) according to the manual and bovine serum albumin (BSA) was used as the standard. Additionally, the contents of carbohydrates and soluble proteins were measured with a UV spectrophotometer (Libra S22, Biochrom Ltd., Cambridge, UK).

\subsection{Enzyme Activities}

The activities of antioxidant enzymes, including peroxidase (POD), catalase (CAT), superoxide dismutase (SOD), and ascorbate peroxidase (APX) were spectrophotometrically measured as described by Manivannan et al. [47]. The key enzymatic activities related to sucrose synthesis: Sucrose synthase (SS), sucrose phosphate synthase (SPS), phosphoenolpyruvate carboxykinase (PEPC), and phosphoenolpyruvate phosphatase (PEPP); starch synthesis: Adenosine diphosphate glucose pyro-phosphorylase (ADPGPPase), uridine diphosphate glucose pyro-phosphorylase (UDGPPase), and soluble starch synthase (SSS); and photosynthesis (RuBisCO) were measured using a UV spectrophotometer (Libra S22, Biochrom Ltd., Cambridge, UK). The SS and SPS activities were determined in a $1 \mathrm{~mL}$ 
reaction mixture containing a $500 \mu \mathrm{L}$ enzyme extract at $34^{\circ} \mathrm{C}$ for $1 \mathrm{~h}$. A $300 \mu \mathrm{L} 30 \%(v / v)$ $\mathrm{KOH}$ was added to this mixture and was then placed in a water bath at $100{ }^{\circ} \mathrm{C}$ for $10 \mathrm{~min}$ after which it was gradually cooled to room temperature. The mixture was subjected to incubation at $40{ }^{\circ} \mathrm{C}$ for $20 \mathrm{~min}$ after a $200 \mu \mathrm{L} 0.15 \%(v / v)$ anthrone-sulfuric acid solution was applied and the enhancement of $\mathrm{A}_{620 \mathrm{~nm}}$ was monitored. The total RuBisCO activity was measured by injecting $100 \mu \mathrm{L}$ of the supernatant into $400 \mu \mathrm{L}$ of an assay mixture consisting of $50 \mathrm{mM}$ Tris- $\mathrm{HCl}(\mathrm{pH} 8.0), 5 \mathrm{mM}$ DTT, $10 \mathrm{mM} \mathrm{MgCl}, 0.1 \mathrm{mM}$ EDTA, and $20 \mathrm{mM} \mathrm{NaH}_{14} \mathrm{CO}_{3}\left(2.0 \mathrm{GBq} \mathrm{mmol}^{-1}\right)$ at $30{ }^{\circ} \mathrm{C}$. After a 5 -min activation period, the reaction was initiated via the addition of RuBP to $0.5 \mathrm{mmol} \mathrm{L}^{-1}$ and was terminated after $30 \mathrm{~s}$ with $100 \mu \mathrm{L}$ of $6 \mathrm{~mol} \mathrm{~L}^{-1} \mathrm{HCl}$. The PEPC was assayed in a $1 \mathrm{~mL}$ reaction mixture consisting of $50 \mathrm{mM}$ Tris- $\mathrm{HCl}$ (pH 8.0), $5 \mathrm{mM} \mathrm{MnCl}_{2}, 2 \mathrm{mM}$ DTT, $10 \mathrm{mM} \mathrm{NaHCO}, 0.2 \mathrm{mM} \mathrm{NADH}$, 5 unit NAD-MDH, and a $160 \mu \mathrm{L}$ enzyme extract. The reaction was initiated by adding $2.5 \mathrm{mM}$ phosphoenolpyruvate (PEP). The PEPP was determined in a $1.5 \mathrm{~mL}$ reaction mixture containing $100 \mathrm{mM}$ imidazole- $\mathrm{HCl}$ ( $\mathrm{pH} 7.5), 50 \mathrm{mM} \mathrm{KCl}, 10 \mathrm{mM} \mathrm{MgCl} 2,0.05 \%(w / v)$ BSA, 2 mM DTT, $150 \mu \mathrm{M}$ NADH, 1 unit LDH, 2 mM ADP, and a $150 \mu \mathrm{L}$ enzyme extract. The reaction was initiated with $2 \mathrm{mM}$ PEP, and the increase in the $\mathrm{A}_{412 \mathrm{~nm}}$ was monitored. The above description of enzymatic activities was conducted in accordance with the directions provided by Feng et al. and Yang et al. [48,49]. In addition, the activities of ADPGPPase, UDPGPPase, and SSS were measured according to the protocol described by Doehlert et al. and Liang et al. [50,51].

\subsection{Real-Time Quantitative PCR Verification}

For each lighting direction, the expanding leaves at the same development stage were harvested $(n=6)$ for consideration of the RNA abundance and the sensitivity of the blade to lighting. All the leaves were immediately frozen in liquid nitrogen. The total RNA was extracted using an Easy-Spin total RNA extraction kit (iNtRON Biotechnology, Seoul, Korea), which was then used for first-strand cDNA synthesis with the GoScript Reverse Transcription System (Promega, Madison, WA, USA) according to the manufacturer's protocols. A real-time quantitative PCR was conducted with a real-time PCR system (CFX96, Bio-Rad, Hercules, CA, USA). The reaction volumes $(20 \mu \mathrm{L})$ contained $1 \mu \mathrm{L}$ of cDNA, $1 \mu \mathrm{L}$ of each amplification primer $(10 \mu \mathrm{M}), 10 \mu \mathrm{L}$ of $2 \times$ AMPIGENE qPCR Green

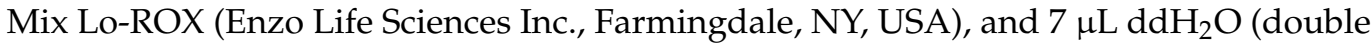
distilled water). The $2-\Delta \Delta C t$ method was used for the data analysis.

The expression level of key genes related to flowering repression and runner formation promotion (FaSOC1 and FaTFL1) and GA biosyntheses (FaGA20ox2 and FaGA20ox4) were measured, and FaMSI1 was the normalization gene (ACTIN) as described [39]. All genes from this article can be found in the GenBank/National Center Biotechnology Information Data Library and the Genome Database for Rosaceae (http: / / www.rosaceae.org, accessed on 2 October 2021). The target gene information and primers are listed in Table 1 [39,52].

Table 1. List of the primers used to quantify the gene expression levels.

\begin{tabular}{|c|c|c|}
\hline Full Name & Accession Number & Primer Sequence $\left(5^{\prime}\right.$ to $\left.3^{\prime}\right)$ \\
\hline $\begin{array}{c}\text { Fragaria ananassa Duch._MUSASHI RNA BINDING } \\
\text { PROTEIN } 1 \\
\text { (FaMSI1) }(\text { ACTIN) }\end{array}$ & Gene03001 & $\begin{array}{l}\text { F: TCCCCACACCTTTGATTGCCA } \\
\text { R: ACACCATCAGTCTCCTGCCAAG }\end{array}$ \\
\hline $\begin{array}{c}\text { Fragaria ananassa Duch._SUPPRESSOR OF } \\
\text { OVEREXPRESSION OF CONSTANS1 } \\
\text { (FaSOC1) }\end{array}$ & FJ531999 & $\begin{array}{l}\text { F: ACTTGCTGGGTTCATTTTCC } \\
\text { R: GAGCTTTCCTCTGGGAGAGA }\end{array}$ \\
\hline $\begin{array}{l}\text { Fragaria ananassa Duch._TERMINAL FLOWER1 } \\
\text { (FaTFL1) }\end{array}$ & JN172097 & $\begin{array}{l}\text { F: CTGGCACCACAGATGCTACA } \\
\text { R: AACGGCAGCAACAGGAAC }\end{array}$ \\
\hline $\begin{array}{l}\text { Fragaria ananassa Duch._GA20-oxidase } 2 \\
(\text { FaGA20ox } 2)\end{array}$ & Gene19438 & $\begin{array}{l}\text { F: GTCCAACATACCACCCCAGT } \\
\text { R: GTTTCTTGCATGCCTCGTC }\end{array}$ \\
\hline $\begin{array}{c}\text { Fragaria ananassa Duch._GA20-oxidase } 4 \\
\text { (FaGA20ox4) }\end{array}$ & Gene09034 & $\begin{array}{l}\text { F: AGGGTGACGATGTAGCAACC } \\
\text { R: CCAGGGAAGTTTTGTGGAGA }\end{array}$ \\
\hline
\end{tabular}




\subsection{Statistical Analysis}

The notable differences among the treatments were assessed via an analysis of variance (ANOVA) followed by Duncan's multiple range test at a probability of $p \leq 0.05$ using a statistical program (SAS, Statistical Analysis System, V. 9.1, Cary, NC, USA). The experimental assays that were used to obtain all of the results were repeated three times and are presented as the mean \pm standard error.

\section{Results}

\subsection{Morphological Characteristics and Growth Parameters}

The morphological and growth characteristics of strawberry 'Sulhyang' plants as affected by the lighting direction after 45 days of cultivation were measured (Figure 1). In this study, the phenotype and growth attributes of strawberry plants were significantly affected by the different lighting directions. The plant height (Figure 1A,D), top view diameter (Figure 1A,E), abaxial petiole angle of the outermost leaves (Figure 1C,G), and leaf width (Figure 1A,I) were considerably increased with the top lighting compared to those with the bottom and side lighting. Specifically, the side lighting definitively and significantly promoted runner formation and plant biomass but decreased the petiole length (Figure 1A,F,L), as compared to the same parameters with the top and bottom lighting. The number and length of leaves and roots were noticeably lower with the bottom lighting than they were with the top and side lighting, but there were no significant differences in these parameters between those grown with the top and side lighting (Figure 1B,H,J-K). Overall, the side and top lighting remarkably increased the plant growth and development, compared to the bottom lighting. It is noteworthy that the side lighting dramatically enhanced while the bottom lighting markedly suppressed runner formation. The bottom lighting also markedly increased the leaf angle and further resulted in strawberry leaves bending downward due to the phototaxis.

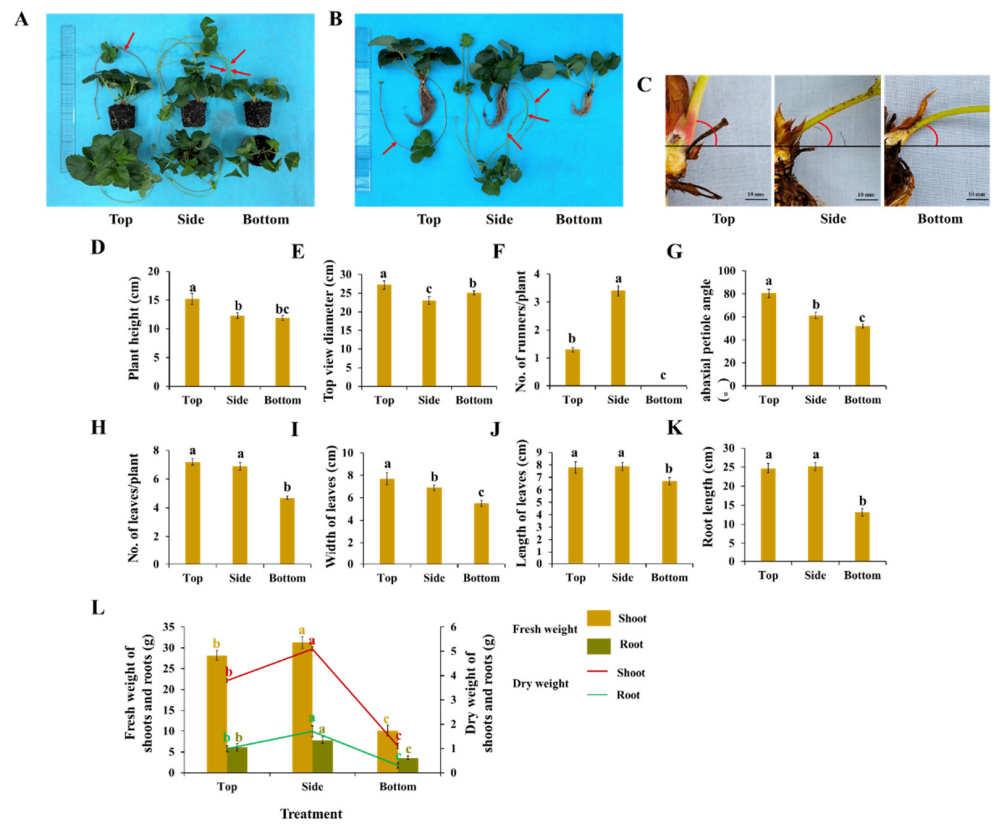

Figure 1. Changes in the phenotype and plant traits of strawberry 'Sulhyang' plants as affected by the lighting direction after 45 days of cultivation. The plant morphology (A), root state and length (B,K), abaxial petiole angle of the outermost leaves $(\mathbf{C}, \mathbf{G})$, plant height (D), top view diameter of plants (E), number of runners per plant $(\mathbf{F})$, number of leaves per plant $(\mathbf{H})$, length and width of the largest fully-expanded leaves $(\mathbf{I}, \mathbf{J})$, fresh and dry weights of plant shoots and roots $(\mathbf{L})$. Vertical bars indicate the means \pm standard error $(n=6)$. Different lowercase letters indicate significant separations within treatments by Duncan's multiple range test at $p \leq 0.05$. Bars indicate $10 \mathrm{~mm}$. Red arrows indicate runners per plant. 


\subsection{Leaf Anatomy}

To further explore the influence of the lighting direction on the leaf structure, the leaf anatomy was investigated in strawberry 'Sulhyang' plants. In this study, visible differences in the leaf, spongy tissue, and palisade tissue thicknesses were examined with regard to the three lighting directions (Figure 2). Interestingly, strawberry leaves displayed a perfectly developed leaf structure with the top and especially the side lighting, with the greatest leaf thickness, as well as a more clear, straight, and compact structures of the palisade tissues and spongy tissues. The mesophyll, composed of palisade parenchyma, spongy parenchyma, and lithocyst, was well developed. The palisade parenchyma was composed of 1-2 layers of cylindrical cells, in which many rectangular lithocysts were arranged perpendicularly to the epidermis. The spongy tissues were comprised of cells of irregular shapes, where some of them were lobed, and separated by large spaces. However, the leaf structures of plants which were grown with the bottom lighting were dysplastic, in particular with the palisade tissues. These findings indicated that an optimal lighting direction positively promotes, while non-optimal lighting negatively affects, the leaf development in strawberry.

A

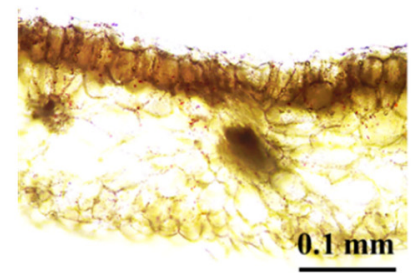

Top

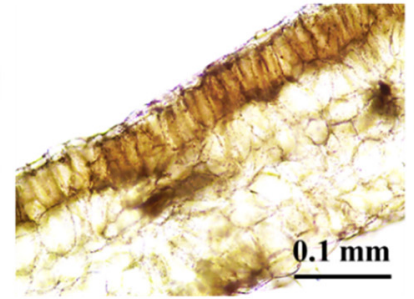

Side

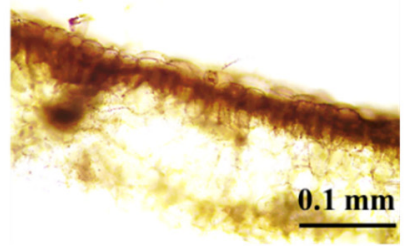

Bottom

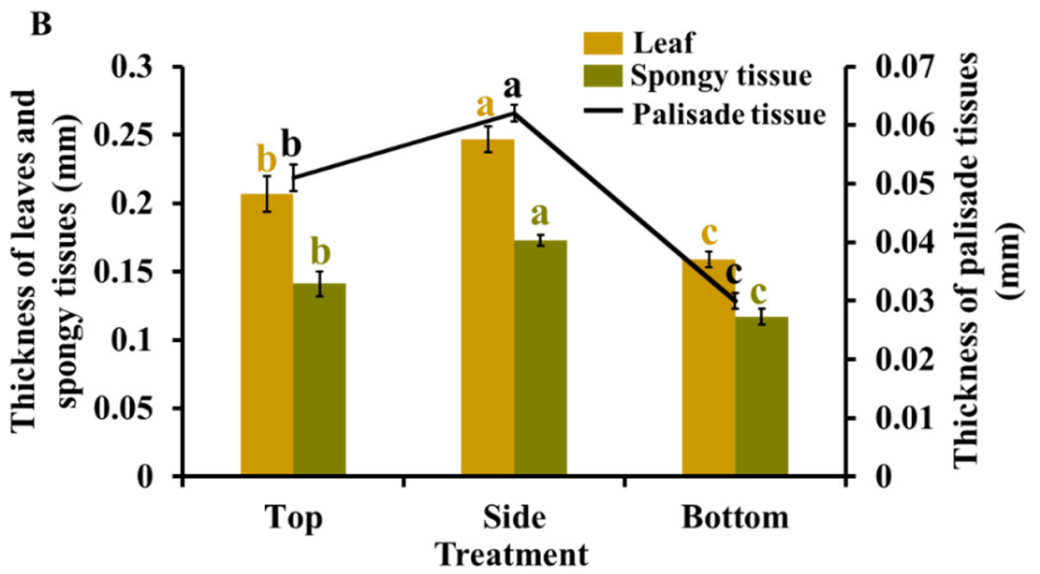

Figure 2. Changes in the leaf structure of strawberry 'Sulhyang' plants as affected by the lighting direction after 45 days of cultivation. Pictorial representation of the leaf structure (A), leaf, spongy tissue, and palisade tissue thickness (B). Vertical bars indicate the means \pm standard error $(n=6)$. Different lowercase letters indicate the significant separation within treatments by Duncan's multiple range test at $p \leq 0.05$. Bars indicate $0.1 \mathrm{~mm}$.

\subsection{Morphology of the Epidermal Cells and Stomata}

The lighting direction exerted a significant influence on the morphology of the epidermal cells of the leaf midribs during their development (Figure 3A-C). The length of the upper epidermal cells was greatly promoted with the top and bottom lighting. The side lighting yielded the greatest width of the upper epidermal cells. Moreover, the smallest values of lower epidermal cell length and width were obtained with the side lighting; these parameters displayed no significant differences in response to the top and bottom lighting. Overall, compared with the top lighting, as plants grew toward the side and bottom lighting, which cause diverse leaf movements, the upper epidermal cells in the 
midribs were stimulated, and became prolate, while the wide flat cells were observed in the lower epidermis because of squeezing.

A

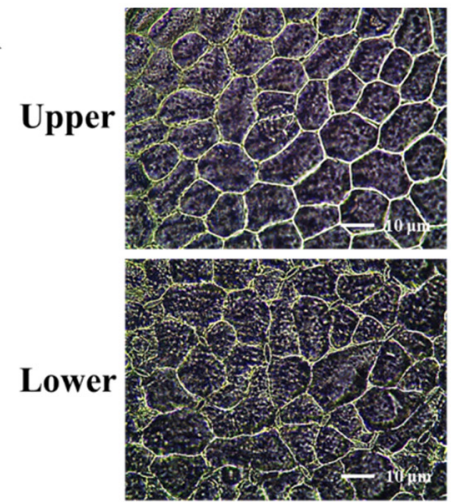

Top
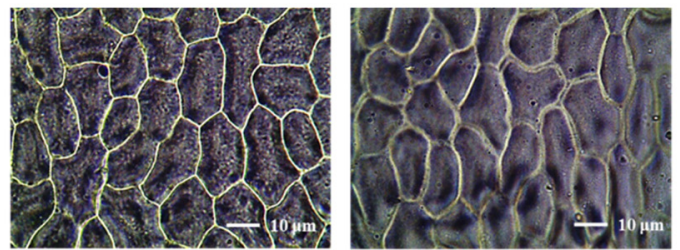

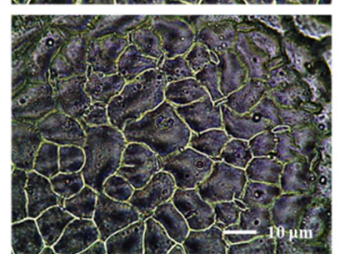

Side

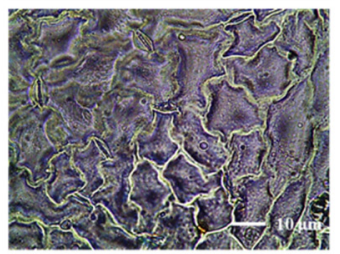

Bottom
B

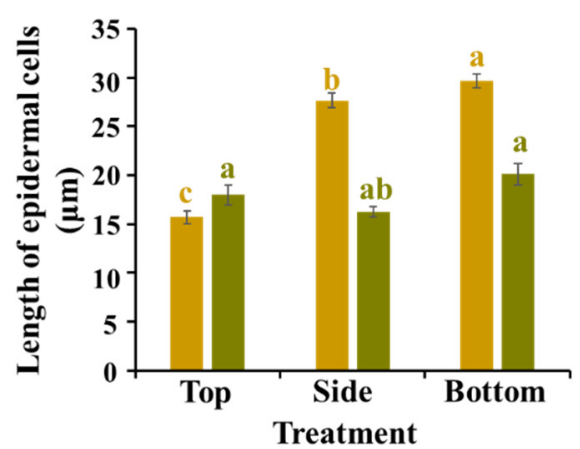

C

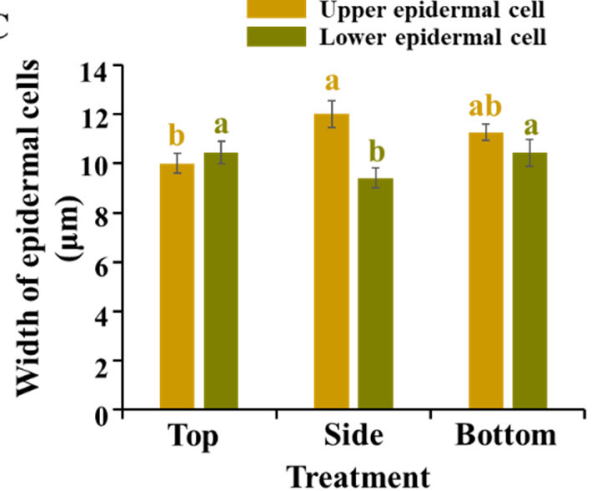

Figure 3. Changes in the upper and lower epidermal cell morphology of strawberry 'Sulhyang' plants as affected by the lighting direction after 45 days of cultivation. Upper and lower epidermal cell morphology (A), cell length (B), and width (C) of strawberry leaves. Vertical bars indicate the means \pm standard error $(n=6)$. Different lowercase letters indicate significant separations within treatments by Duncan's multiple range test at $p \leq 0.05$. Bars indicate $10 \mu \mathrm{m}$.

To further explore the changes in the epidermal cellular morphology, we examined the stomatal state in strawberry leaves as affected by the different lighting directions. Relative to the bottom lighting, the top and especially the side lighting significantly increased the stomatal density and promoted stomatal opening (Figures 4 and 5A,E). Moreover, few opened but many closed stomatal pores were observed in response to the bottom lighting (Figure 4A). In addition, the bottom lighting yielded the most narrow and shriveled guard cell pairs and stomatal pores, as well as poorly distributed chloroplasts in guard cells. However, the round and plump guard cells containing numerous chloroplasts were found in response to the top, and especially the side lighting. Moreover, the side lighting resulted in a smaller stomatal size than the top and especially the bottom lighting (Figure 5A). Our results indicated that the top and especially the side lighting resulted in a much more prominent increase in the stomatal density and stomatal opening, but smaller stomatal size when compared to the bottom lighting. Overall, different lighting directions resulted in different changes in the strawberry leaf phenotype and further affected the morphology of the epidermal cells and stomata, and eventually led to changes in the stomatal properties. 
A

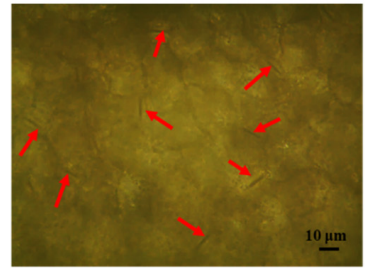

Top

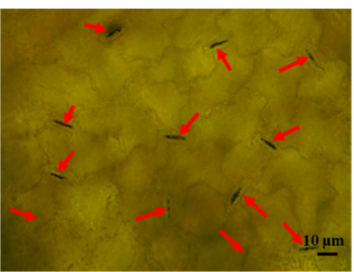

Side

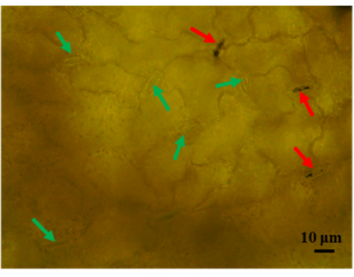

Bottom

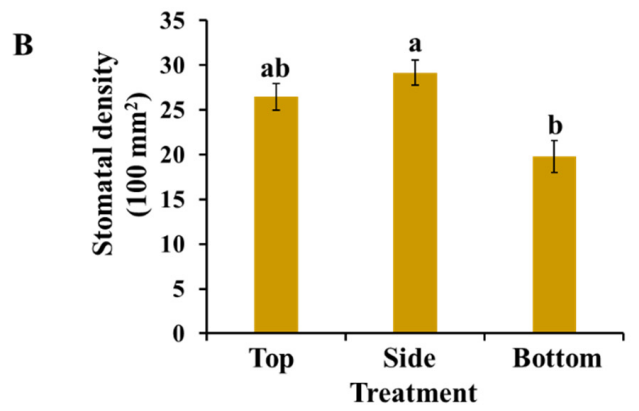

Figure 4. Stomatal micrographs $(\mathbf{A})(10 \times)$ and changes in the stomatal density $(\mathbf{B})$ of strawberry 'Sulhyang' plants as affected by the lighting direction after 45 days of cultivation. Vertical bars indicate the means \pm standard error $(n=6)$. Different lowercase letters indicate significant separations within treatments by Duncan's multiple range test at $p \leq 0.05$. Bars indicate $10 \mu \mathrm{m}$. Red arrows indicate opened stomatal pores, green arrows indicate closed stomatal pores.

A

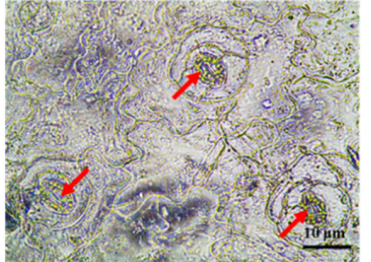

Top

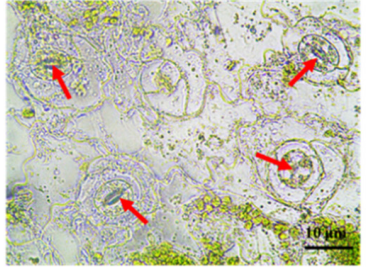

Side

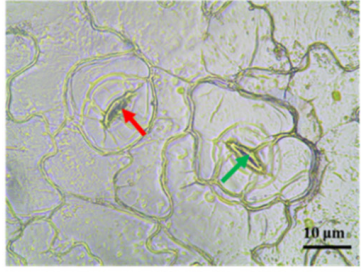

Bottom
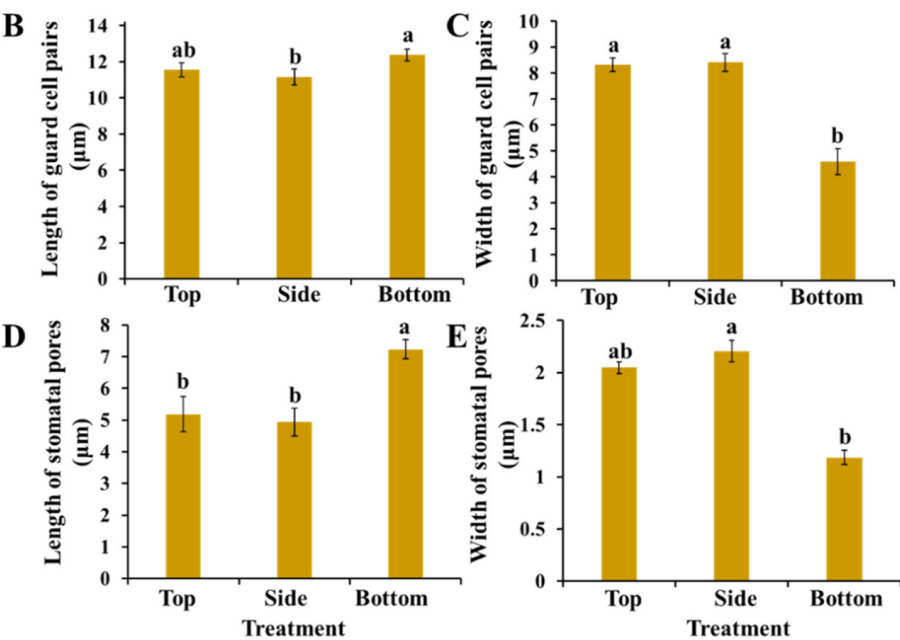

Figure 5. Stomatal micrographs (A) $(40 \times)$ and changes in the stomatal properties of strawberry 'Sulhyang' plants as affected by the lighting direction after 45 days of cultivation. Length (B) and width $(\mathbf{C})$ of guard cell pairs, length (D) and width (E) of stomatal pores. Vertical bars indicate the means \pm standard error $(n=6)$. Different lowercase letters indicate significant separations within treatments by Duncan's multiple range test at $p \leq 0.05$. Bars indicate $10 \mu \mathrm{m}$. Red arrows indicate opened stomatal pores, while green arrows indicate closed stomatal pores. 


\subsection{Photosynthetic Pigment Contents}

The lighting direction significantly affected the photosynthetic pigment contents in strawberry leaves (Figure 6). In this experiment, the bottom lighting distinctly decreased the values of $\mathrm{Chl} \mathrm{a,Chl} \mathrm{b,} \mathrm{Chl} \mathrm{a}+b$, and Car contents, but not Chl a/b. Greater Chl and Car contents were observed with the top and side lighting, and the side slighting led to the greatest pigment contents. Moreover, there were no significant differences in the $\mathrm{Chl}$ $\mathrm{a} / \mathrm{b}$ in response to the top and side lighting. On average, these improvements in $\mathrm{Chl}$ and Car contents suggest a direct relationship between the photosynthetic pigment contents and the lighting direction: the bottom lighting negatively affected pigment formations in strawberry plants.

A

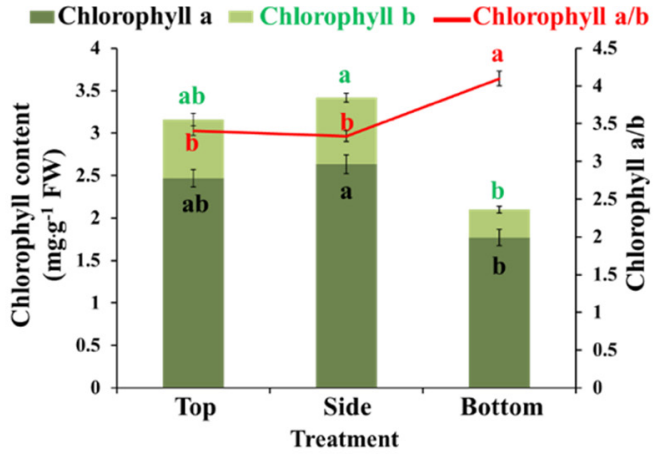

B

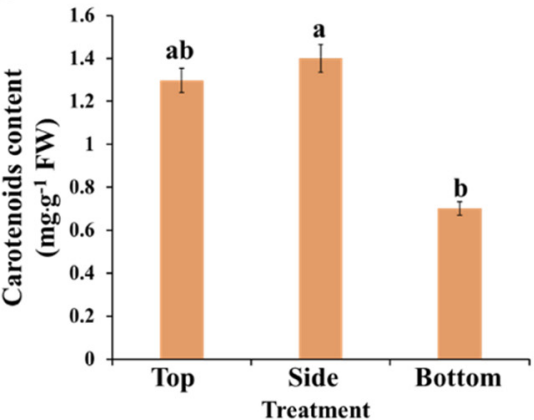

Figure 6. Changes in the photosynthetic pigment contents in strawberry 'Sulhyang' as affected by the lighting direction after 45 days of cultivation. Chlorophyll contents and chlorophyll a to $\mathrm{b}$ ratio (A), carotenoids contents $(\mathbf{B})$. Vertical bars indicate the means \pm standard error $(n=6)$. Different lowercase letters indicate significant separations within treatments by Duncan's multiple range test at $p \leq 0.05$.

\subsection{Photosynthetic and Chlorophyll Fluorescence Characteristics}

Table 2 shows the photosynthetic characteristics of strawberry plants in response to the different lighting directions. The maximum $P_{\mathrm{n}}, T_{\mathrm{r}}, G_{\mathrm{s}}$, and $C_{\mathrm{i}}$ values of strawberry leaves were observed in response to the side lighting, while the bottom lighting led to a marked decline. Relative to the bottom lighting, the increases in the net photosynthetic rate in response to the top and side lighting indicated that the lighting direction is highly linked with photosynthesis. This relationship may be due to the enhancement of the stomatal properties and photosynthetic pigment contents when the top and especially the side lighting were employed.

Table 2. Influence of the lighting direction on the photosynthetic characteristics of strawberries grown for 45 days.

\begin{tabular}{|c|c|c|c|c|}
\hline $\begin{array}{l}\text { Lighting } \\
\text { Direction }\end{array}$ & $\begin{array}{c}P_{\mathrm{n}}{ }^{1} \\
\left(\mu \mathrm{mol} \mathrm{CO}_{2}\right. \\
\left.\mathrm{m}^{-2} \cdot \mathrm{s}^{-1}\right)\end{array}$ & $\begin{array}{c}T_{\mathrm{r}}^{2} \\
\left(\mathrm{mmol} \mathrm{H}_{2} \mathrm{O}\right. \\
\left.\mathrm{m}^{-2} \cdot \mathrm{s}^{-1}\right)\end{array}$ & $\begin{array}{c}G_{\mathrm{s}}{ }^{3} \\
\left(\mathrm{~mol} \mathrm{H}_{2} \mathrm{O}\right. \\
\left.\mathrm{m}^{-2} \cdot \mathrm{s}^{-1}\right)\end{array}$ & $\begin{array}{c}C_{\mathrm{i}}{ }^{4} \\
\left(\mu \mathrm{mol} \mathrm{CO}_{2}\right. \\
\left.\mathrm{mol}^{-1}\right)\end{array}$ \\
\hline Top & $13.1 b^{5}$ & $1.79 \mathrm{ab}$ & $0.59 \mathrm{~b}$ & $439.6 \mathrm{ab}$ \\
\hline Side & $14.4 \mathrm{a}$ & $1.84 \mathrm{a}$ & $0.67 \mathrm{a}$ & $462.7 \mathrm{a}$ \\
\hline Bottom & $11.3 \mathrm{c}$ & $1.29 \mathrm{~b}$ & $0.33 c$ & $371.9 \mathrm{~b}$ \\
\hline
\end{tabular}

${ }^{1}$ Net photosynthetic rate. ${ }^{2}$ Transpiration rate. ${ }^{3}$ Stomatal conductance. ${ }^{4}$ Intercellular $\mathrm{CO}_{2}$ concentration. ${ }^{5}$ Mean separation within columns by Duncan's multiple range test at $p \leq 0.05$.

The absorbed radiation energy in strawberry leaves was studied in response to the different lighting directions (Table 3). In this experiment, the chlorophyll fluorescence parameters including $F_{\mathrm{v}} / F_{\mathrm{m}}, F_{\mathrm{v}}{ }^{\prime} / F_{\mathrm{m}}{ }^{\prime}, \mathrm{NPQ}$, and $q P$ were significantly altered in response to the different lighting directions. Moreover, the $F_{\mathrm{v}} / F_{\mathrm{m}}, F_{\mathrm{v}}{ }^{\prime} / F_{\mathrm{m}}{ }^{\prime}, \mathrm{NPQ}$, and $q P$ with 
the top and side lighting were considerably higher than those with the bottom lighting, while insignificant differences were observed in response to the top and side lighting. Furthermore, the side lighting observably increased the quantum yields of $F_{\mathrm{v}} / F_{\mathrm{m}}, F_{\mathrm{v}}{ }^{\prime} / F_{\mathrm{m}}{ }^{\prime}$, NPQ, and $q P$ by $22.8,40.8,32.1$, and $64.7 \%$, respectively, as compared to those with the bottom lighting. Overall, our results indicated that the provision of an appropriate lighting direction plays a crucial role in improving the chlorophyll fluorescence parameters and photosynthetic capacity of strawberry plants.

Table 3. Influence of the lighting direction on the chlorophyll fluorescence characteristics of strawberries grown for 45 days.

\begin{tabular}{ccccc}
\hline Lighting Direction & $\boldsymbol{F}_{\mathbf{v}} / \boldsymbol{F}_{\mathbf{m}}{ }^{\mathbf{1}}$ & $\boldsymbol{F}_{\mathbf{v}}{ }^{\prime} / \boldsymbol{F}_{\mathbf{m}^{\prime}}{ }^{\mathbf{2}}$ & $\mathbf{N P Q} \mathbf{3}^{\mathbf{3}}$ & $\boldsymbol{q \boldsymbol { P } ^ { \mathbf { 4 } }}$ \\
\hline Top & $0.90 \mathrm{~b}^{5}$ & $0.61 \mathrm{~b}$ & $2.79 \mathrm{a}$ & $0.52 \mathrm{ab}$ \\
\hline Side & $0.97 \mathrm{a}$ & $0.69 \mathrm{a}$ & $2.80 \mathrm{a}$ & $0.56 \mathrm{a}$ \\
\hline Bottom & $0.79 \mathrm{c}$ & $0.49 \mathrm{c}$ & $2.12 \mathrm{~b}$ & $0.34 \mathrm{~b}$ \\
\hline
\end{tabular}

${ }^{1}$ The maximal PSII quantum yield $\left(F_{\mathrm{v}} / F_{\mathrm{m}}\right) .{ }^{2}$ The photochemical efficiency of PSII $\left(F_{\mathrm{v}}{ }^{\prime} / F_{\mathrm{m}}{ }^{\prime}\right){ }^{3}$ Non-photochemical quenching (NPQ). ${ }^{4}$ Coefficient of photochemical quenching $(q P)^{5}$ Mean separation within columns by Duncan's multiple range test at $p \leq 0.05$.

\subsection{Carbohydrates and Soluble Proteins}

The different lighting directions led to differences in the photosynthetic efficiency (Tables 2 and 3). To further investigate the effects of the lighting direction on photosynthesis, we determined the accumulation of soluble proteins in strawberry plants (Figure 7A). The content of soluble proteins was the lowest with the bottom lighting, while the greatest value was observed with the side lighting. In our study, the lighting direction also affected the total soluble sugar and starch contents (Figure 7B,C). As expected, the total soluble sugar and starch contents significantly increased in response to the side lighting. The highest total soluble sugar content of $2.2 \mathrm{mg} \mathrm{g}^{-1}$ and starch content of $12.1 \mathrm{mg} \mathrm{g}^{-1}$ were measured in response to the side lighting. Moreover, the increasing tendency of the total soluble sugar and starch contents proved again that a highly positive relationship exists between the side lighting and photosynthesis.
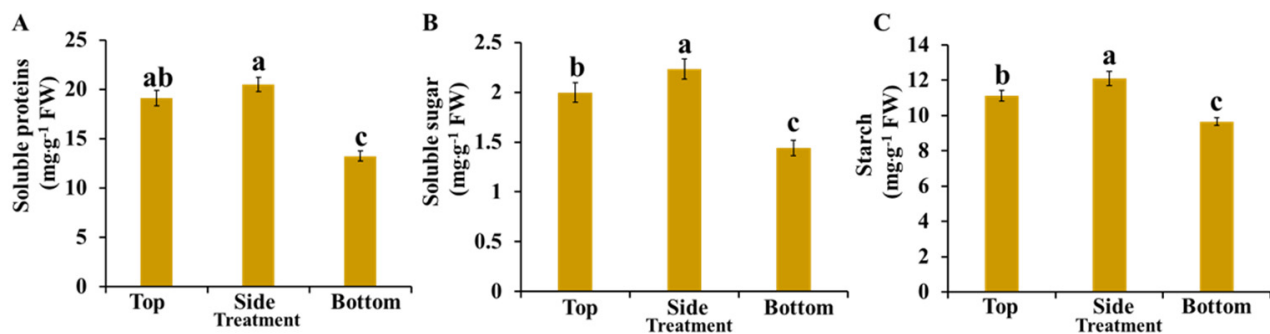

Figure 7. Changes in the contents of soluble proteins (A) and carbohydrates (B,C) of strawberry 'Sulhyang' plants as affected by the lighting direction after 45 days of cultivation. Vertical bars indicate the means \pm standard error $(n=6)$. Different lowercase letters indicate significant separations within treatments by Duncan's multiple range test at $p \leq 0.05$.

\subsection{Enzymatic Activities}

We further explore the effects of the lighting direction on the enzymatic activities in strawberry plants. The significant differences in the activity of ROS scavenging enzymes (APX, CAT, GPX, and SOD) (Figure 8A-D), sucrose synthesis enzymes (SS, SPS, PEPC, and PEPP) (Figure 8E,F), starch synthesis enzymes (ADPGPPase, UDGPPase, and SSS) (Figure 8G-I), and photosynthesis enzymes (activated and non-activated activity of RuBisCO) (Figure 8J) were investigated in response to the different lighting directions. As expected, all the aforementioned enzymatic activities decreased with the bottom lighting, compared to those with the top and side lighting, and the lowest values were measured 
with the bottom lighting. An acceleration in the activity of these enzymes occurred for both the top and side lighting, while the amplitude of acceleration was higher with the side lighting than with the top lighting. Taken together, these results suggest that the different enzymatic activities were directly associated with changes in the lighting direction. In our situation, using side lighting can be more effective at stimulating enzymatic activities.

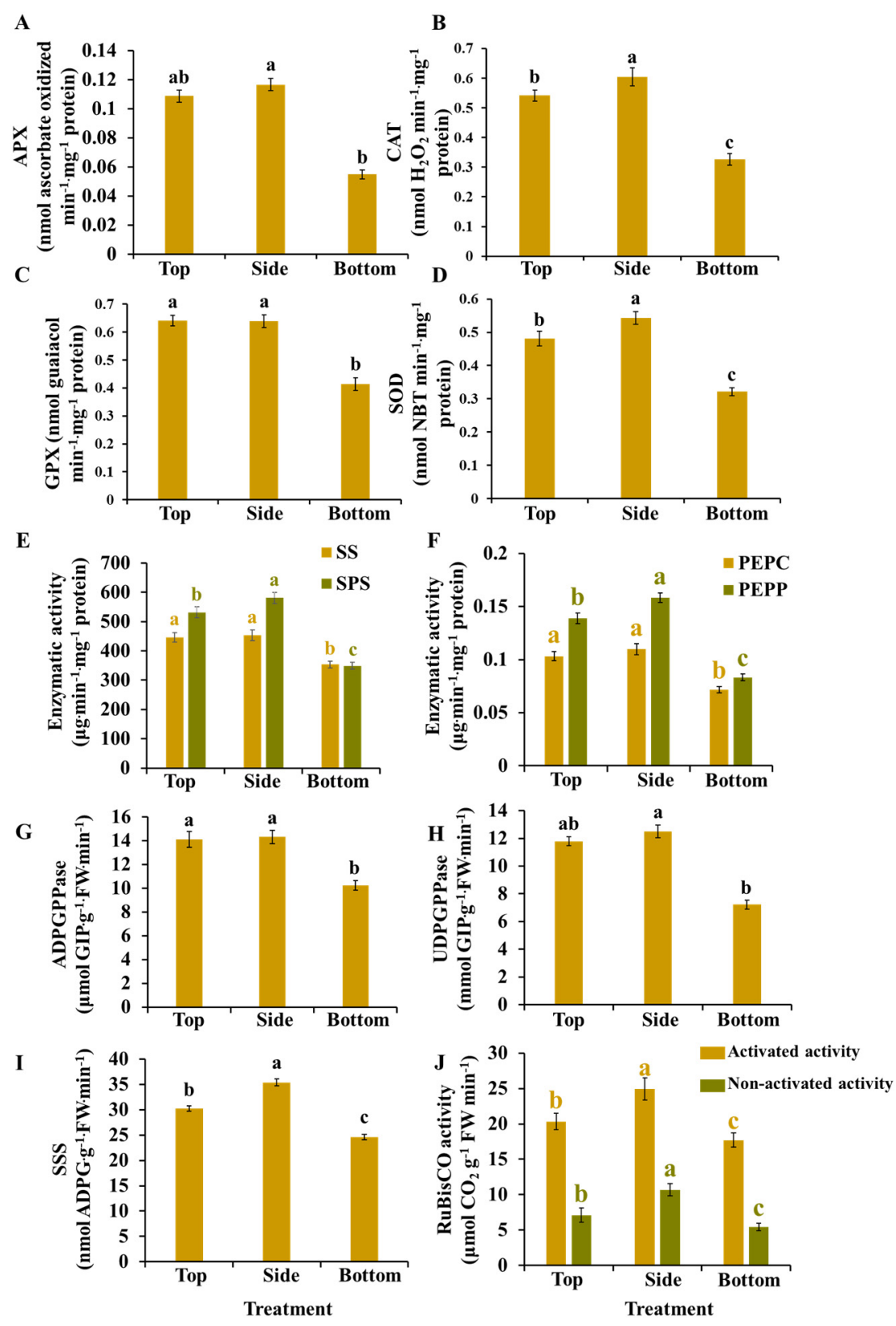

Figure 8. Changes in the enzymatic activities in strawberry 'Sulhyang' as affected by the lighting direction after 45 days of cultivation. The ROS scavenging enzymatic activities: Ascorbate peroxidase (APX) (A), catalase (CAT) (B), guaiacol peroxidase (GPX) (C), and superoxide peroxidase (SOD) (D). Sucrose synthesis enzymatic activities: Sucrose synthase (SS) and sucrose phosphate synthase (SPS) (E), phosphoenolpyruvate carboxykinase (PEPC) and phosphoenolpyruvate phosphatase (PEPP) (F). Starch synthesis enzymatic activities: Adenosine diphosphate glucose pyro-phosphorylase (ADPGPPase) (G), uridine diphosphate glucose pyro-phosphorylase (UDGPPase) (H), and soluble starch synthase (SSS) (I). Photosynthesis enzymatic activities: Activated and non-activated activity of RuBisCO (J). Vertical bars indicate the means \pm standard error $(n=6)$. Different lowercase letters indicate significant separations within treatments by Duncan's multiple range test at $p \leq 0.05$. 


\subsection{Gene Expressions}

A very interesting phenomenon was observed in our experiment, where conspicuous differences in the phenotype of runner formation were observed in response to the three lighting directions. As we mentioned previously, FaSOC1 and FaTFL1 are two key genes that play a major role in the control of flowering and vegetative reproduction through runners. GAs are considered potentially important regulators of tuber growth. So, the key genes related to flowering repression and runner formation promotion (FaSOC1 and FaTFL1), as well as the GA biosyntheses-related genes (FaGA20ox2 and FaGA20ox4), were investigated in our study (Figure 9A-D). All genes were down-regulated with the bottom lighting, while the side lighting led to the greatest expression levels. The gene expression tendencies were consistent with the phenotype of runner formation in the experiment, where the side lighting promoted the formation of a greater number of runners; no runners were induced in response to the bottom lighting. Our experimental results proved that there was a direct or indirect relationship between the lighting direction and runner formation, referring to the gene-controlled networks and GA biosyntheses-related pathways. However, the specific connections need to be explored further.

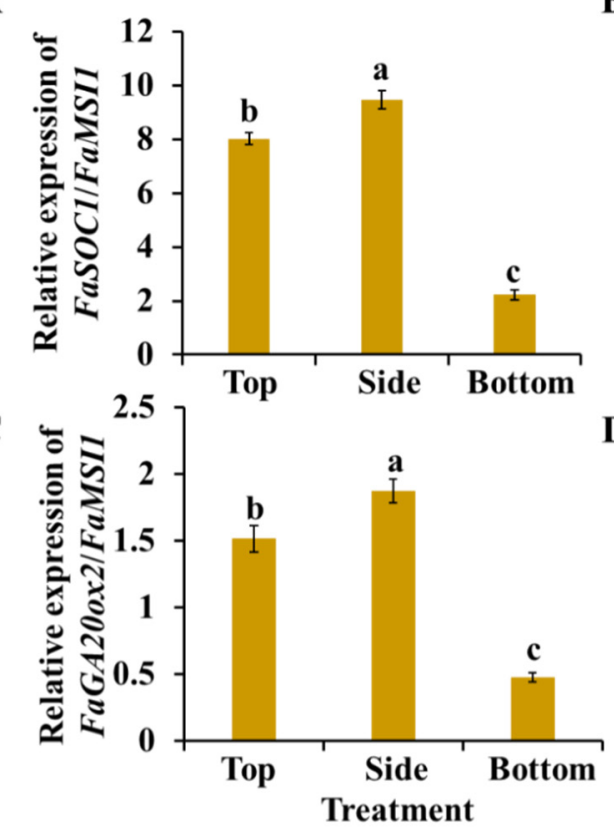

B
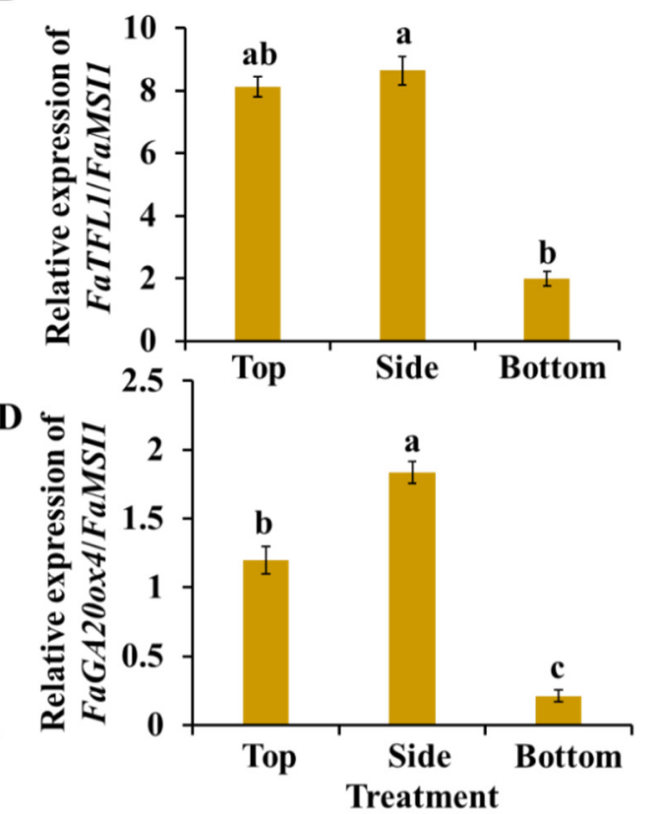

Figure 9. Changes in the gene expression levels in strawberry 'Sulhyang' plants as affected by the lighting direction after 45 days of cultivation. Flowering repression and runner formation promotionrelated genes (FaSOC1 and FaTFL1) (A,B), GA biosyntheses-related genes (FaGA20ox2 and FaGA20ox4) $(\mathbf{C}, \mathbf{D})$. Verticsal bars indicate the means \pm standard error $(n=6)$. Different lowercase letters indicate significant separations within treatments by Duncan's multiple range test at $p \leq 0.05$.

\section{Discussion}

\subsection{The Effects of the Lighting Direction on Morphology and Growth Parameters of Strawberry Plants}

The morphology of plants has a certain plasticity, and the corresponding adaptation mechanisms exist for different environmental conditions [53]. Numerous reports have confirmed that the lighting quality, intensity, source, and photoperiod led to various influences on the plant morphology. However, a few experiments have investigated the impact of different lighting directions on the plant growth and development. In our study, the bottom lighting significantly decreased the plant height, top view diameter, leaf area, number of leaves per plant, root length, plant biomass, and abaxial petiole angle of the outermost leaves of strawberry plants as compared to the parameters in response to the 
top and side lighting (Figure 1). These results indicated that any change in the lighting direction directly affected the morphological characteristics of strawberries, and that the bottom lighting negatively affected the strawberry growth and development. Similarly, in a previous study, it has been reported that the bottom lighting significantly influenced the morphology and growth state by reducing the abaxial petiole angle, plant height, and dry matter production [18]. Due to phototropism, differences in the lighting direction induced the epinastic or hyponastic leaf movement in plants. The strawberries that were grown with the bottom lighting had the smallest abaxial petiole angle, followed by the plants grown with the side lighting, and the bottom lighting also led to the lowest shoot height. The side lighting remarkably enhanced the fresh and dry weights of shoots and roots but reduced the shoot height, which is consistent with the results of a study which reported that in vitro micropropagated potato plantlets grown with sideward lighting had significantly shortened stems but an increased dry weight compared to those grown with the top (downward) lighting [54]. In addition, the greatest plant growth and development of strawberries were observed with the top and side lighting, which may be regulated by higher photosynthesis, which supplies adequate energy to the plants [55] and involves complex molecular regulation networks and endogenous plant hormones [56,57]. Overall, these results demonstrated that the top and side lighting are more effective in improving strawberry growth and development, compared to the bottom lighting.

\subsection{The Effects of the Lighting Direction on Runner Induction and Runner-Formation-Related Gene Expression in Strawberry Plants}

It is worth noting that the side lighting promoted more runners than the top lighting did, while there was no runner formation induced with the bottom lighting. Recently, some reports have proven that sugar is crucial for bud outgrowth. For nearly a century, the plant growth regulator auxin has been central to theories on apical dominance, whereby the growing shoot tip suppresses the growth of the axillary buds below. The rate of auxin transportation is very slow, typically at $1 \mathrm{~cm} \mathrm{~h}^{-1}$ through the stem [58], but it has been observed that pea (Pisum satioum) buds release up to $24 \mathrm{~h}$ before changes in the auxin content were observed in the adjacent stem. After the loss of the shoot tip, sugars are rapidly redistributed over large distances $\left(150 \mathrm{~cm} \mathrm{~h}^{-1}\right)$ and accumulate in axillary buds within a timeframe that correlates with the bud release. Thus, a new theory of apical dominance was put forward, where it was proposed that the shoot tip's strong demand for sugars inhibits axillary bud outgrowth by limiting the amount of sugars translocated to those buds [59]. Furthermore, recent studies have shown that sugar not only plays a nutritional role, but also serves as a significant signaling mediator for the bud release. For instance, sugar could suppress the auxin-induced strigolactone pathway to promote bud growth in rose (Rosa hybrida L. cv Radrazz) [60]. Moreover, higher expression levels of sugar metabolism and signaling genes were detected in non-dormant buds in strawberry runners when compared with those in dormant buds [61]. Thus, we measured the soluble sugar and starch contents in strawberries treated with the different lighting directions. Depending on our results, the top and especially the side lighting processed higher soluble sugar and starch contents than the bottom lighting did (Figure 7B,C). Moreover, the carbohydrate contents were positively correlated with the number of runners, suggesting that carbohydrates may play an important role in breaking the dormancy of the axillary buds and inducing runner formation in strawberry plants. As we know, RuBisCo is a key enzyme for photosynthesis, and its activity is extremely crucial for photosynthesis [62]. In addition, the top and especially the side lighting enhanced the activity of RuBisCo and photosynthetic parameters (Figure 8J, Tables 2 and 3) indicate that photosynthesis was promoted with both the top and side lighting, which led to an increased production of carbohydrates. These results indicate that the top and especially the side lighting increased the carbohydrate contents, which can promote runner formation by enhancing photosynthesis.

GAs are the most diverse plant hormones, and play a significant role in regulating the internode elongation, fiber development, leaf growth, flowering, fruiting, and seed 
dormancy in higher plants. Currently, 136 natural GAs are known, but only a few GA molecules (such as $\mathrm{GA}_{1}, \mathrm{GA}_{3}, \mathrm{GA}_{4}$, and $\mathrm{GA}_{7}$ ) are biologically active in plants [63]. Surapornpiboon [64] found that runner production was negatively correlated with the $\mathrm{GA}_{3}$ concentration in cultivated strawberry, which is consistent with our previous results where it was found that exogenous $\mathrm{GA}_{3}$ application decreased the number of runners [65]. In addition, cultivated strawberries are complex allo-octoploids, with four relatively similar sub-genomic chromosome sets from diploid donors. A polyploid usually produces more hormones, total proteins, sugars, flavonoids, etc., compared to the corresponding diploid [66-68]. It could be deduced that the octoploids could increase the level of GAs, and these GAs alone are enough for producing runners in 'Sulhyang'. Thus, the GA 3 application broke the dynamic equilibrium and reduced the runner formation [65]. Taken together, GAs have been shown to play a critical role in runner formation in woodland strawberries.

GA20-oxidase is a key synthesizing and regulating enzyme in the biosynthesis of gibberellic acid and directly regulates the generation of biological GAs. It is also a multifunctional enzyme, and its most important feature is negative feedback regulation. GA20oxidase plays an important regulating role in the development and physiological processes of plants [69]. In our experiment, the higher expression levels of GA20-oxidase synthesisrelated genes ( $F a G A 20 o x 2$ and $F a G A 20 o x 4)$ were observed in strawberry plants which were grown with the top and especially side lighting, which is consistent with the results concerning the phenotype of runner formation. These results demonstrated that the lighting direction is correlated with the biosynthesis of GAs, and the side lighting observably promoted biosynthesis of GAs compared to the top and bottom lighting.

Moreover, FaSOC1 regulates the differentiation of axillary buds to runners or axillary leaf rosettes, probably through the activation of gibberellin-biosynthesis-related genes $[39,52,70]$. In addition, the function of FaTFL1 as a major floral repressor and its photoperiodic control in the shoot apex explains seasonal flowering in strawberries. High FaTFL1 expression is restored in the apices of new branch crowns to allow the production of new vegetative shoots [71]. Some studies have also reported that FaSOC1 is regulated by FaFLT1, suggesting that it plays a central role in the photoperiodic control of both generative and vegetative growth in strawberry. In conclusion, we propose that the top and especially the side lighting increased the FaSOC1 and FaFLT1 expression, resulting in suppressed flowering and promoted runner formation. However, these genes are just the signaling hubs that regulate the vegetative and generative development through separate genetic pathways, and future studies have yet to explore the mechanisms of runner formation.

\subsection{The Effects of the Lighting Direction on the Epidermal Cells, Stomatal State, and Leaf Anatomy of Strawberry Leaves}

In our research, we further explored the effects of the lighting direction on morphology at the cellular level. For the strawberry plants grown with the bottom and side lighting, the shoots generally displayed positive phototropism [72], whereby they bend toward the light to capture and more efficiently use the available light (Figure 1A) [73]. As a result of the hyponastic leaf movement in plants, the adaxial leaf petiole angle increased and the leaves bent toward the light source (Figure 1C). The upper epidermal cells in the midribs were stimulated, and became prolate, while the wide flat cells were observed in the lower epidermis because of the squeezing (Figure 3A).

A stoma is a pore found in the epidermis of leaves, stems, and other plant organs that controls the rate of gas exchange. The epinastic or hyponastic leaf movements induced epidermal cell deformation due to phototropism, and further stimulated the stomatal state. Guard cells are pulled or squeezed, causing the stomata to close or open (Figures 4 and 5). In our study, the strawberry plants grown with the side lighting exhibited the greatest density of smaller size stomata, followed by the top lighting, while the bottom lighting led to significantly lower number of bigger size stomata. Notably, the top and especially the side lighting promoted stomatal opening, but not the bottom lighting (Figures $4 \mathrm{~A}$ and $5 \mathrm{~A}$ ). 
Consequently, higher photosynthetic efficiency and stress resistance that were observed in strawberry plants grown with the top and especially the side lighting may be due to the favorable stomatal conditions $[21,74,75]$. Thereby, the greatest levels of biomass production, plant growth, and development were observed with the top and side lighting (Figure 1).

It is well known that there is a close relationship between the morphology and physiology during plant growth and development. Moreover, the differences in the photosynthetic rate are highly related to the leaf anatomical structures. The results of this study have shown that an improved leaf structure can be obtained in strawberry leaves with the top and especially the side lighting (Figure 2). In addition, the side lighting led to the greatest increases in the leaf, spongy tissue, and palisade tissue thicknesses, followed by the top lighting. The greater leaf area ensured a high light interception capacity and photosynthetic efficiency. The photosynthetic rate was found to be sensitive to the leaf and the amount of carbon partitioned led to leaves growing thicker, which further promoted the development of the leaf structures [76,77]. The observed improvements in the thicknesses of anatomical leaf structures with the side lighting may be linked with the well-developed mesophyll tissues [78]. The bottom lighting produced leaves with smaller cell sizes and loose cell layers, meaning that the thicknesses of the palisade tissues and spongy tissues were small, which may be due to the reduced cell growth and cell layer number in the mesophyll tissues [79]. Overall, the top and especially the side lighting increased the palisade tissue elongation process and development of the spongy tissues, which enhanced the attachment region of the chloroplast and facilitated the passage of gases through its intercellular spaces [80]. Consequently, the thickness and the photosynthetic capacity of the strawberry leaves were significantly strengthened $[81,82]$ with the side and top lighting.

\subsection{The Effects of the Lighting Direction on Photosynthetic Pigment Contents, Photosynthetic Parameters, and Primary Metabolite Yields of Strawberry Plants}

Photosynthesis is the most affected by the photosynthetic pigment contents. During our experiment, significant changes were observed in the chlorophyll ( $\mathrm{Chl}$ a, $\mathrm{Chl} \mathrm{b}$, and $\mathrm{Chl}$ $\mathrm{a}+\mathrm{b}$ ) and carotenoid (Car) contents with the different lighting directions. The side lighting led to the greatest performance (Figure 6). These results were directly associated with the leaf thickness and chloroplast redundancy (Figures 2 and 5). Our results are consistent with those reported in other studies $[83,84]$.

In addition to the effects of the lighting direction on the morphology, leaf anatomy, and photosynthetic pigment contents, our findings demonstrate that the deleterious impacts of inappropriate lighting directions are reduced with optimal light conditions. In this study, the top and especially the side lighting led to an enhanced $P_{n}, T_{r}, G_{\mathrm{S}}$, and $C_{\mathrm{i}}$ of strawberry plants compared to those with the bottom lighting. Thus, this showed that the improved photosynthetic parameters enhanced the carbon gain and promoted growth of strawberry plants [85]. Moreover, these results suggest that an increase in the net photosynthetic rate which results from the side and top lighting may be due to the increases in the stomatal opening [86-88].

An increased photosynthetic capacity is always accompanied by a high quantity of electrons passing through PSII. Chlorophyll fluorescence characteristics are the main factors of photosynthetic regulation and plant responses to environmental conditions because of their sensitivity and convenience [89]. Chlorophyll fluorescence parameters are closely related to various reactions of photosynthesis, and the effects of any stress on a certain process of photosynthesis can be reflected by the fluorescence kinetics of chlorophyllin [90]. Previous studies have reported that fluorescence parameters demonstrated a significantly positive linear relationship with the chlorophyll content in the living leaves of plants [91]. In the present study, similar results were obtained, and improved chlorophyll fluorescence characteristics were observed with the top and especially the side lighting. These results reveal that optimal lighting directions enhance the efficiency of PSII, and that they could enhance photosynthesis by improving the energy transport from PSII to PSI. 
Furthermore, the lighting direction influenced the accumulation of the primary metabolites in strawberry plants. Carbohydrates, including starch and soluble sugars, are the direct expression of strong photosynthesis, and carbohydrate accumulation plays an important role in the plant growth, development, and morphology [92]. The content of soluble proteins is an important physiological and biochemical index and is an important indicator for understanding the overall metabolism of plants. Our data showed that the side and top lighting enhanced the carbohydrate and soluble protein levels (Figure 7), as a combined effect of the stomatal properties, photosynthetic pigment contents, and use efficiency of light provided in different directions. These results were in general agreement with those of previous studies [18]. The lighting direction played an important role in regulating the soluble protein levels and enzymes related to carbohydrates.

\subsection{The Effects of the Lighting Direction on Enzymatic Activities of Strawberry Plants}

To overcome the unfavorable conditions, plants have developed sophisticated acclimatization strategies, such as the ROS scavenging enzymatic antioxidant system [26]. ROS production is a common phenomenon in plants under stresses. Under such circumstances, the balance between ROS production and quenching activities of antioxidants is disturbed, often resulting in oxidative damages [27]. Usually, a greater ability to eliminate ROS indicates higher antioxidant enzyme activities. Moreover, $\mathrm{Chl}$ a is more sensitive to ROS than $\mathrm{Chl} b$ is, and under stress conditions, ROS directly caused the degradations of Chl a and the total chlorophyll contents [28,29]. In our study, the highly active ROS scavenging system involving POD, CAT, etc., occurred with the top and especially the side, but not the bottom lighting (Figure $8 \mathrm{~A}-\mathrm{D}$ ). By comprehensively analyzing the previous results, the chlorophyll content was observed to be positively correlated with the activity of the ROS scavenging antioxidant system, and the side lighting effectively improved the chlorophyll content, the antioxidant capacity of the antioxidant enzyme system, and stress resistance in strawberry plants.

The enzymatic activities of the key enzymes involved in carbohydrate synthesis and photosynthesis significantly increased in response to the top and especially the side lighting. Moreover, changes in the lighting direction also played major roles in accelerating the activities of SS, SPS, and PEPC. Therefore, the plant biomass and net photosynthetic rate, which were upregulated with the side lighting, may be affected by the increased activities of these key enzymes and controlled the cell elongation and division in plants (Figure 8E-J). These results indicate that the higher carbohydrate contents provided by these enzymes were a response to the optimal lighting environments. In this case, plants grown with the side lighting can be considered to be more effective at performing enzymatic activities. Furthermore, the activity of RuBisCO was increased with the side lighting, which demonstrated that the higher net photosynthetic rate in strawberry plants is directly correlated with the RuBisCO activity under changing lighting environments.

\section{Conclusions}

In this study, we investigated how strawberries responded to different lighting directions to help fine-tune the growth environment for their development. In the plant factory-type chambers, side lighting visibly enhanced the morphophysiology, especially the runner formation, through upregulation of photosynthesis in strawberries. Moreover, we demonstrated that the expression level of runner induction-related genes ( $F a S O C 1$ and FaTFL1) and GA biosyntheses-related genes ( $F a G A 20 o x 2$ and FaGA20ox4) were positively correlated with the side lighting, which suggested that the side lighting may play an important role in photosynthesis enhancement, runner induction-related plant hormone adjustment, and runner formation in strawberries. Further investigation remains necessary to explore the differences in the internal hormone distribution, concertation, and adjustment in response to various lighting directions. 


\begin{abstract}
Author Contributions: Conceptualization, B.R.J.; methodology, B.R.J. and J.Y.; software, J.Y. and J.S.; validation, B.R.J.; formal analysis, B.R.J. and J.Y.; investigation, J.Y. and J.S.; resources, B.R.J.; data curation, J.Y.; writing—original draft preparation, J.Y.; writing-review and editing, B.R.J. and J.Y.; supervision, B.R.J.; project administration, B.R.J.; funding acquisition, B.R.J. All authors have read and agreed to the published version of the manuscript.
\end{abstract}

Funding: This research received no external funding. Jingli Yang and Jinnan Song were supported by the BK21 Four Program, Ministry of Education, Korea.

Institutional Review Board Statement: Not applicable.

Informed Consent Statement: Not applicable.

Data Availability Statement: Data sharing is not applicable to this article.

Conflicts of Interest: The authors declare no conflict of interest.

\title{
References
}

1. Hossain, M.R.; Natarajan, S.; Kim, H.T.; Jesse, D.M.I.; Lee, C.G.; Park, J.I.; Nou, I.S. High density linkage map construction and QTL mapping for runner production in allo-octoploid strawberry Fragaria $\times$ ananassa based on ddRAD-seq derived SNPs. Sci. Rep. 2019, 9, 1-11. [CrossRef] [PubMed]

2. Caruana, J.C.; Sittmann, J.W.; Wang, W.; Liu, Z. Suppressor of runnerless encodes a DELLA protein that controls runner formation for asexual reproduction in strawberry. Mol. Plant 2018, 11, 230-233. [CrossRef] [PubMed]

3. Savini, G.; Neri, D.; Zucconi, F.; Sugiyama, N. Strawberry growth and flowering: An architectural model. Int. J. Fruit Sci. 2005, 5, 29-50. [CrossRef]

4. Hytönen, T.; Elomaa, P. Genetic and environmental regulation of flowering and runnering in strawberry. Genes Genom. Genom. 2011, 5, 56-64.

5. Hytönen, T.; Palonen, P.; Mouhu, K.; Junttila, O. Crown branching and cropping potential in strawberry $($ Fragaria $\times$ ananassa Duch.) can be enhanced by daylength treatments. J. Hortic. Sci. Biotechnol. 2004, 79, 466-471. [CrossRef]

6. Liu, C.; Guo, Z.; Park, Y.G.; Wei, H.; Jeong, B.R. PGR and its application method affect number and length of runners produced in 'Maehyang' and 'Sulhyang'strawberries. Agronomy 2019, 9, 59. [CrossRef]

7. Uddin, A.J.; Hossan, M.; Islam, M.; Ahsan, M.; Mehraj, H. Strawberry growth and yield responses to gibberellic acid concentrations. J. Expt. Biosci. 2012, 3, 51-56.

8. Kumar, R.; Bakshi, M.; Singh, D. Influence of plant growth regulators on growth, yield and quality of strawberrry $($ Fragaria $\times$ ananassa Duch.) under UP sub tropics. Asian, J. Hortic. 2012, 7, 434-436.

9. Palei, S.; Das, K.; Sahoo, K.; Dash, D.K.; Swain, S. Influence of plant growth regulators on strawberry cv. chandler under odisha condition. Int. J. Sci. Res. 2016, 7, 9945-9948.

10. Tian, F. Study and Optimization of Lighting Systems for Plant Growth in a Controlled Environment. Ph.D. Thesis, Universite Paul Sabatier-Toulouse III, Toulouse, France, 2016.

11. Mcnellis, T.W.; Deng, X.W. Light control of seedling morphogenetic pattern. Plant Cell 1995, 7, 1749-1761.

12. Chen, M.; Chory, J.; Fankhauser, C. Light signal transduction in higher plants. Annu. Rev. Genet. 2004, 38, 87-117. [CrossRef] [PubMed]

13. Ahmed, H.A.; Tong, Y.X.; Yang, Q.C. Optimal control of environmental conditions affecting lettuce plant growth in a controlled environment with artificial lighting: A review. S. Afr. J. Bot. 2020, 130, 75-89. [CrossRef]

14. Schneider, S.C.; Pichler, D.E.; Andersen, T.; Melzer, A. Light acclimation in submerged macrophytes: The roles of plant elongation, pigmentation and branch orientation differ among Chara species. Aquat. Bot. 2015, 120, 121-128. [CrossRef]

15. Kendrick, R.E.; Kronenberg, G.H. Photomorphogenesis in Plants, 2nd ed.; Springer Science \& Business Media: Berlin, Germany, 2012.

16. Liscum, E.; Askinosie, S.K.; Leuchtman, D.L.; Morrow, J.; Willenburg, K.T.; Coats, D.R. Phototropism: Growing towards an understanding of plant movement. Plant Cell 2014, 26, 38-55. [CrossRef] [PubMed]

17. Wang, M.; Wei, H.; Jeong, B.R. Lighting direction affects leaf morphology, stomatal characteristics, and physiology of head lettuce (Lactuca sativa L.). Int. J. Mol. Sci. 2021, 22, 3157. [CrossRef] [PubMed]

18. Yang, J.; Jeong, B.R. Side lighting enhances morphophysiology by inducing more branching and flowering in chrysanthemum grown in controlled environment. Int. J. Mol. Sci. 2021, 22, 12019. [CrossRef] [PubMed]

19. Sack, L.; Buckley, T.N. The developmental basis of stomatal density and flux. Plant Physiol. 2016, 171, 2358-2363. [CrossRef]

20. Ren, X.; Liu, Y.; Jeong, H.K.; Jeong, B.R. Supplementary light source affects the growth and development of Codonopsis lanceolata seedlings. Int. J. Mol. Sci. 2018, 19, 3074. [CrossRef]

21. Kardel, F.; Wuyts, K.; Babanezhad, M.; Wuytack, T.; Potters, G.; Samson, R. Assessing urban habitat quality based on specific leaf area and stomatal characteristics of Plantago lanceolata L. Environ. Pollut. 2010, 158, 788-794. [CrossRef]

22. Schreiber, U.; Bilger, W.; Neubauer, C. Chlorophyll fluorescence as a nonintrusive indicator for rapid assessment of in vivo photosynthesis. In Ecophysiology of Photosynthesis; Springer: Berlin, Germany, 1995; pp. 49-70. 
23. Rascher, U.; Liebig, M.; Lüttge, U. Evaluation of instant light-response curves of chlorophyll fluorescence parameters obtained with a portable chlorophyll fluorometer on site in the field. Plant Cell Environ. 2000, 23, 1397-1405. [CrossRef]

24. Yao, X.; Li, C.; Li, S.; Zhu, Q.; Zhang, H.; Wang, H.; Yu, C.; Martin, S.K.S.; Xie, F. Effect of shade on leaf photosynthetic capacity, light-intercepting, electron transfer and energy distribution of soybeans. Plant Growth Regul. 2017, 83, 409-416. [CrossRef]

25. Wu, Y.S.; Feng, Y.; Gong, W.Z.; Ahmed, S.; Fan, Y.F.; Wu, X.L.; Yong, T.W.; Liu, W.G.; Kai, S.; Jiang, L. Shade adaptive response and yield analysis of different soybean genotypes in relay intercropping systems. J. Integr. Agric. 2017, 16, 1331-1340. [CrossRef]

26. Song, J.N.; Liu, X.H.; Wang, Y.Q.; Yang, H.B. Transcriptome analysis reveals salinity responses in four Tartary buckwheat cultivars. J. Plant Biochem. Biotechnol. 2021, 30, 1-15. [CrossRef]

27. Lotfi, R.; Pessarakli, M.; Gharavi, K.P.; Khoshvaghti, H. Physiological responses of Brassica napus to fulvic acid under water stress: Chlorophyll a fluorescence and antioxidant enzyme activity. Crop. J. 2015, 3, 434-439. [CrossRef]

28. Huang, P.; Jia, D.; Yuan, Z.; Mei, S.; Ye, Y. Physiological responses of exotic weeds Gaura parviflora to drought stress. J. Northeast Agric. Univ. 2011, 42, 102-106.

29. Huang, C.J.; Wei, G.; Jie, Y.C.; Xu, J.J.; Zhao, S.Y.; Wang, L.C.; Anjum, S.A. Responses of gas exchange, chlorophyll synthesis and ROS-scavenging systems to salinity stress in two ramies (Boehmeria nivea L.) cultivars. Photosynthetica 2015, 53, 455-463. [CrossRef]

30. Seemann, J.R.; Sharkey, T.D. Salinity and nitrogen effects on photosynthesis, ribulose-1,5-bisphosphate carboxylase and metabolite pool sizes in Phaseolus vulgaris L. Plant Physiol. 1986, 82, 555-560. [CrossRef]

31. Delfine, S.; Alvino, A.; Villani, M.C.; Loreto, F. Restrictions to carbon dioxide conductance and photosynthesis in spinach leaves recovering from salt stress. Plant Physiol. 1999, 119, 1101-1106. [CrossRef]

32. Redondo-Gómez, S.; Mateos, N.E.; Davy, A.J.; Fernández-Muñoz, F.; Castellanos, E.M.; Luque, T.; Figueroa, M.E. Growth and photosynthetic responses to salinity of the salt-marsh shrub Atriplex portulacoides. Ann. Bot. 2007, 100, 555-563. [CrossRef]

33. Kao, W.Y.; Tsai, T.T.; Shih, C.N. Photosynthetic gas exchange and chlorophyll $a$ fluorescence of three wild soybean species in response to $\mathrm{NaCl}$ treatments. Photosynthetica 2003, 41, 415-419. [CrossRef]

34. Ranjbarfordoei, A.; Samson, R.; Van Damme, P. Chlorophyll fluorescence performance of sweet almond [Prunus dulcis (Miller) D. Webb] in response to salinity stress induced by $\mathrm{NaCl}$. Photosynthetica 2006, 44, 513-522. [CrossRef]

35. Stępień, P.; Kłbus, G. Water relations and photosynthesis in Cucumis sativus L. leaves under salt stress. Biol. Plant. 2006, 50, 610-616. [CrossRef]

36. Mauser, H.; King, W.A.; Gready, J.E.; Andrews, T.J. $\mathrm{CO}_{2}$ fixation by rubisco: Computational dissection of the key steps of carboxylation, hydration, and C-C bond cleavage. J. Am. Chem. Soc. 2001, 123, 10821-10829. [CrossRef] [PubMed]

37. Slovin, J.P.; Schmitt, K.; Folta, K.M. An inbred line of the diploid strawberry Fragaria vesca f. semperflorens for genomic and molecular genetic studies in the Rosaceae. Plant Methods 2009, 5, 15. [CrossRef]

38. Tenreira, T.; Lange, M.J.P.; Lange, T.; Bres, C.; Labadie, M.; Monfort, A.; Hernould, M.; Rothan, C.; Denoyes, B. A specific gibberellin 20-oxidase dictates the flowering-runnering decision in diploid strawberry. Plant Cell 2017, 29, 2168-2182. [CrossRef] [PubMed]

39. Mouhu, K.; Kurokura, T.; Koskela, E.A.; Albert, V.A.; Elomaa, P.; Hytönen, T. The fragaria vesca homolog of SUPPRESSOR OF OVEREXPRESSION OF CONSTANS1 represses flowering and promotes vegetative growth. Plant Cell 2013, 25, 3296-3310. [CrossRef] [PubMed]

40. Martins, A.O.; Nunes-Nesi, A.; Araújo, W.L.; Fernie, A.R. To bring flowers or do a runner: Gibberellins make the decision. Mol. Plant 2018, 11, 4-6. [CrossRef]

41. Chen, B.H.; Li, X.S.; Cao, Z.Y. A method for observing stoma by transparent gummed tape to tear epidermis from leaf. Plant Physiol. Commun. 2004, 40, 215-218.

42. Sims, D.A.; Gamon, J.A. Relationships between leaf pigment content and spectral reflectance across a wide range of species, leaf structures and developmental stages. Remote Sens. Environ. 2002, 81, 337-354. [CrossRef]

43. Maxwell, K.; Johnson, G.N.; Maxwell, K.; Johnson, G.N. Chlorophyll fluorescence-a practical guide. J. Exp. Bot. 2000, 51, 659-668. [CrossRef]

44. Vasseur, F.; Pantin, F.; Vile, D. Changes in light intensity reveal a major role for carbon balance in Arabidopsis responses to high temperature. Plant Cell Environ. 2011, 34, 1563-1576. [CrossRef] [PubMed]

45. Ren, X.X.; Xue, J.Q.; Wang, S.L.; Xue, Y.Q.; Zhang, P.; Jiang, H.D.; Zhang, X.X. Proteomic analysis of tree peony (Paeonia ostii ‘Feng Dan') seed germination affected by low temperature. J. Plant Physiol. 2018, 224, 56-67. [CrossRef] [PubMed]

46. Bianco, L.; Lopez, L.; Scalone, A.G.; Di Carli, M.; Desiderio, A.; Benvenuto, E.; Perrotta, G. Strawberry proteome characterization and its regulation during fruit ripening and in different genotypes. J. Proteom. 2009, 72, 586-607. [CrossRef] [PubMed]

47. Manivannan, A.; Soundararajan, P.; Arum, L.S.; Ko, C.H.; Muneer, S.; Jeong, B.R. Silicon-mediated enhancement of physiological and biochemical characteristics of Zinnia elegans 'Dreamland Yellow' grown under salinity stress. Hortic. Environ. Biotechnol. 2015, 56, 721-731. [CrossRef]

48. Feng, L.; Raza, M.A.; Li, Z.; Chen, Y.; Khalid, M.H.B.; Du, J.; Liu, W.; Wu, X.; Song, C.; Yu, L. The influence of light intensity and leaf movement on photosynthesis characteristics and carbon balance of soybean. Front. Plant Sci. 2019, 9, 1952. [CrossRef]

49. Yang, L.T.; Chen, L.S.; Peng, H.Y.; Guo, P.; Wang, P.; Ma, C.L. Organic acid metabolism in Citrus grandis leaves and roots is differently affected by nitric oxide and aluminum interactions. Sci. Hortic. 2012, 133, 40-46. [CrossRef] 
50. Doehlert, D.C.; Kuo, T.M.; Felker, F.C. Enzymes of sucrose and hexose metabolism in developing kernels of two inbreds of maize. Plant Physiol. 1988, 86, 1013-1019. [CrossRef]

51. Liang, J.S.; Cao, X.; Xu, S.; Zhu, Q.; Song, P. Studies on the relationship between the grain sink strength and its starch accumulation in rice (O. Sativa). Acta Agron. Sin. 1994, 20, 685-691.

52. Zhou, Y.; Li, Y.; Gong, M.; Qin, F.; Xiao, D.; Zhan, J.; Wang, A.; He, L. Regulatory mechanism of GA 3 on tuber growth by DELLA-dependent pathway in yam (dioscorea opposita). Plant Mol. Biol. 2021, 17, 1-16. [CrossRef]

53. Kumar, A.; Grewal, A.S.; Singh, V.; Narang, R.; Pandita, D.; Lather, V. Synthesis, antimicrobial activity and QSAR studies of some new sparfloxacin derivatives. Pharm. Chem. J. 2018, 52, 444-454. [CrossRef]

54. Kozai, T.; Kino, S.; Jeong, B.; Kinowaki, M.; Ochiai, M.; Hayashi, M.; Mori, K. A sideward lighting system using diffusive optical fibers for production of vigorous micropropagated plantlets. In International Symposium on Transplant Production Systems; International Society for Horticultural Science: Leuven, Belgium, 1992; Volume 319, pp. $237-242$.

55. Van, G.K.; Kang, C.; Pierik, R. Light signaling, root development, and plasticity. Plant Physiol. 2018, 176, 1049-1060.

56. Vandenbussche, F.; Pierik, R.; Millenaar, F.F.; Voesenek, L.A.; Van Der Straeten, D. Reaching out of the shade. Curr. Opin. Plant Biol. 2005, 8, 462-468. [CrossRef] [PubMed]

57. Sheerin, D.J.; Hiltbrunner, A. Molecular mechanisms and ecological function of far-red light signaling. Plant Cell Environ. 2017, 40, 2509-2529. [CrossRef] [PubMed]

58. Morris, S.E.; Cox, M.C.; Ross, J.J.; Krisantini, S.; Beveridge, C.A. Auxin dynamics after decapitation are not correlated with the initial growth of axillary buds. Plant Physiol. 2005, 138, 1665-1672. [CrossRef] [PubMed]

59. Mason, M.G.; Ross, J.J.; Babst, B.A.; Wienclaw, B.N.; Beveridge, C.A. Sugar demand, not auxin, is the initial regulator of apical dominance. Proc. Natl. Acad. Sci. USA 2014, 111, 6092-6097. [CrossRef] [PubMed]

60. Bertheloot, J.; Barbier, F.; Boudon, F.; Perez-Garcia, M.D.; Péron, T.; Citerne, S.; Dun, E.; Beveridge, C.; Godin, C.; Sakr, S. Sugar availability suppresses the auxin-induced strigolactone pathway to promote bud outgrowth. New Phytol. $2020,225,866-879$. [CrossRef] [PubMed]

61. Qiu, Y.; Guan, S.C.; Wen, C.; Li, P.; Gao, Z.; Chen, X. Auxin and cytokinin coordinate the dormancy and outgrowth of axillary bud in strawberry runner. BMC Plant. Biol. 2019, 19, 528. [CrossRef] [PubMed]

62. Farhat, N.; Elkhouni, A.; Zorrig, W.; Smaoui, A.; Abdelly, C.; Rabhi, M. Effects of magnesium deficiency on photosynthesis and carbohydrate partitioning. Acta Physiol. Plant. 2016, 38, 145. [CrossRef]

63. Tudzynski, B. Biosynthesis of gibberellins in Gibberella fujikuroi: Biomolecular aspects. Appl. Microbiol. Biot. 1999, 52, 298-310. [CrossRef]

64. Surapornpiboon, P.; Surapornpiboon, P. Effect of benzyladenine and gibberellic acid on runner production in strawberry. In Proceedings of the 19 Rajamangala University of Technology Conference, Pathum Thani, Thailand, 22-27 January 2002.

65. Li, Y.; Hu, J.; Wei, H.; Jeong, B.R. A long-day photoperiod and 6-benzyladenine promote runner formation through upregulation of soluble sugar content in strawberry. Int. J. Mol. Sci. 2020, 21, 4917. [CrossRef]

66. Dai, F.; Wang, Z.; Luo, G.; Tang, C. Phenotypic and transcriptomic analyses of autotetraploid and diploid mulberry (Morus alba L.). Int. J. Mol. Sci. 2015, 16, 22938-22956. [CrossRef] [PubMed]

67. Jaskani, M.J.; Kwon, S.W.; Kim, D.H. Comparative study on vegetative, reproductive and qualitative traits of seven diploid and tetraploid watermelon lines. Euphytica 2005, 145, 259-268. [CrossRef]

68. Bagheri, M.; Mansouri, H. Effect of induced polyploidy on some biochemical parameters in Cannabis sativa L. Appl. Biochem. Biotech. 2015, 175, 2366-2375. [CrossRef] [PubMed]

69. Wu, J.M.; Chen, R.F.; Huang, X.; Qiu, L.H.; Li, Y.R. Studies on the gene of key component GA20-oxidase for gibberellin biosynthesis in Plant. Biotech. Bull. 2016, 32, 1-12.

70. Kurokura, T.; Samad, S.; Koskela, E.; Mouhu, K.; Hytönen, T. Fragaria vesca CONSTANS controls photoperiodic flowering and vegetative development. J. Exp. Bot. 2017, 68, 4839-4850. [CrossRef] [PubMed]

71. Koskela, E.A.; Mouhu, K.; Albani, M.C.; Kurokura, T.; Rantanen, M.; Sargent, D.J.; Battey, N.H.; Coupland, G.; Elomaa, P.; Hytönen, T. Mutation in TERMINAL FLOWER1 reverses the photoperiodic requirement for flowering in the wild strawberry fragaria vesca. Plant Physiol. 2012, 159, 1043-1054. [CrossRef] [PubMed]

72. Millenaar, F.F.; Van Zanten, M.; Cox, M.C.; Pierik, R.; Voesenek, L.A.; Peeters, A.J. Differential petiole growth in Arabidopsis thaliana: Photocontrol and hormonal regulation. New Phytol. 2009, 184, 141-152. [CrossRef]

73. Pierik, R.; Cuppens, M.L.; Voesenek, L.A.; Visser, E.J. Interactions between ethylene and gibberellins in phytochrome-mediated shade avoidance responses in tobacco. Plant Physiol. 2004, 136, 2928-2936. [CrossRef]

74. Niresh, J.; Kirubakaran, R.; Mohana Praddeesh, M.; Gokul, V.; Gokkul, T. An optimized observer for estimating torque converter characteristics for vehicles with automatic transmission. Int. J. Eng. Technol. 2018, 7, 573-577.

75. Jumrani, K.; Bhatia, V.S.; Pandey, G.P. Impact of elevated temperatures on specific leaf weight, stomatal density, photosynthesis and chlorophyll fluorescence in soybean. Photosynth. Res. 2017, 131, 333-350. [CrossRef]

76. Weraduwage, S.M.; Chen, J.; Anozie, F.C.; Morales, A.; Weise, S.E.; Sharkey, T.D. The relationship between leaf area growth and biomass accumulation in Arabidopsis thaliana. Front. Plant Sci. 2015, 6, 167. [CrossRef]

77. Marchi, S.; Tognetti, R.; Minnocci, A.; Borghi, M.; Sebastiani, L. Variation in mesophyll anatomy and photosynthetic capacity during leaf development in a deciduous mesophyte fruit tree (Prunus persica) and an evergreen sclerophyllous Mediterranean shrub (Olea europaea). Trees 2008, 22, 559-571. [CrossRef] 
78. Waldhoff, D.; Parolin, P. Morphology and anatomy of leaves. In Amazonian Floodplain Forests; Springer: Berlin/Heidelberg, Germany, 2010; pp. 179-202.

79. Kalve, S.; Fotschki, J.; Beeckman, T.; Vissenberg, K.; Beemster, G.T. Three-dimensional patterns of cell division and expansion throughout the development of Arabidopsis thaliana leaves. J. Exp. Bot. 2014, 65, 6385-6397. [CrossRef] [PubMed]

80. Terashima, I.; Inoue, Y. Palisade tissue chloroplasts and spongy tissue chloroplasts in spinach: Biochemical and ultrastructural differences. Plant Cell Physiol. 1985, 26, 63-75.

81. Niinemets, Ü. Research review. Components of leaf dry mass per area-thickness and density-alter leaf photosynthetic capacity in reverse directions in woody plants. New Phytol. 1999, 144, 35-47. [CrossRef]

82. Sims, D.A.; Pearcy, R.W. Response of leaf anatomy and photosynthetic capacity in Alocasia macrorrhiza (Araceae) to a transfer from low to high light. Am. J. Bot. 1992, 79, 449-455. [CrossRef]

83. Wittmann, C.; Aschan, G.; Pfanz, H. Leaf and twig photosynthesis of young beech (Fagus sylvatica) and aspen (Populus tremula) trees grown under different light regime. Basic Appl. Ecol. 2001, 2, 145-154. [CrossRef]

84. Borsuk, A.M.; Brodersen, C.R. The spatial distribution of chlorophyll in leaves. Plant Physiol. 2019, 180, 1406-1417. [CrossRef] [PubMed]

85. Liao, J.X.; Ge, Y.; Huang, C.C.; Zhang, J.; Liu, Q.X.; Chang, J. Effects of irradiance on photosynthetic characteristics and growth of Mosla chinensis and M. scabra. Photosynthetica 2005, 43, 111-115. [CrossRef]

86. Yin, Q.; Tian, T.; Kou, M.; Liu, P.; Wang, L.; Hao, Z.; Yue, M. The relationships between photosynthesis and stomatal traits on the loess plateau. Glob. Ecol. Conserv. 2020, 23, e01146. [CrossRef]

87. Ma, J.; Zhu, Q.S.; Ma, W.B.; Tian, Y.H.; Yang, J.C.; Zhou, K.D. Studies on the photosynthetic characteristics and assimilate's accumulation and transformation in heavy panicle type of rice. Agric. Sci. China 2003, 2, 602-608.

88. Yamori, W.; Kusumi, K.; Iba, K.; Terashima, I. Increased stomatal conductance induces rapid changes to photosynthetic rate in response to naturally fluctuating light conditions in rice. Plant Cell Environ. 2020, 43, 1230-1240. [CrossRef] [PubMed]

89. Dai, Y.; Shen, Z.; Liu, Y.; Wang, L.; Hannaway, D.; Lu, H. Effects of shade treatments on the photosynthetic capacity, chlorophyll fluorescence, and chlorophyll content of Tetrastigma hemsleyanum Diels et Gilg. Environ. Exp. Bot. 2009, 65, 177-182. [CrossRef]

90. Liang, Y.; Feng, L.; Yin, C. Current status and prospect of chlorophyll fluorescence technique in the study of responses of microalgae to environmental stress. Mar. Sci.-QingDao 2007, 31, 71.

91. Zhang, Y.; Liu, G.J. Effects of cesium accumulation on chlorophyll content and fluorescence of Brassica juncea L. J. Environ. Radioact. 2018, 195, 26-32. [CrossRef] [PubMed]

92. Liu, Y.; Ren, X.; Jeong, B.R. Supplementary light source affects growth, metabolism, and physiology of Adenophora triphylla (Thunb.) A.DC. seedlings. Biomed. Res. Int. 2019, 2019, 1-16. [CrossRef] 